\title{
ADAM protein family - its role in tumorigenesis, mechanisms of chemo- resistance and potential as diagnostic and prognostic factors
}

\author{
Minireview
}

L. ZADKA ${ }^{1,2, *}$, M. J. KULUS ${ }^{1}$, K. PIATEK ${ }^{3}$

${ }^{1}$ Department of Human Morphology and Embryology, Division on Histology and Embryology, Wroclaw Medical University, Wroclaw, Poland; ${ }^{2}$ II Department of Psychiatry and Psychiatric Rehabilitation, Medical University of Lublin, Lublin, Poland; ${ }^{3}$ Department of Endocrinology, Metabolism and Internal Diseases, Poznan University of Medical Science, Poznan, Poland

${ }^{*}$ Correspondence: ceadr7@gmail.com

Received December 20, 2017 / Accepted March 15, 2018

\begin{abstract}
ADAMs are a family of transmembrane proteins described for the first time in the 1990's. ADAMs is an abbreviation of "A Disintegrin and Metallo-proteinases". Their earliest known role was involvement in gamete fusion, and their adhesion properties in intercellular interactions also suggested involvement in tumor biology. Further research emphasized the importance of ADAM proteins in the regulation of neoplastic processes due to their influence on adhesion, cell migration, proteolysis and cell signaling. Variable ADAM expression in cancer and normal tissue was the basis for considering these proteins as diagnostic markers. Recent numerous studies have been published suggesting the prognostic value of this protein family members. The ADAMs transmembrane proteins regulate processes associated with carcinogenesis and neoplastic progression, including immune response evasion, growth induction and metastasis. Proteolysis and shedding of membrane proteins and binding integrins by ADAMs lead to the activation of numerous growth factors, changes in the extracellular matrix, adhesion proteins and angiogenesis. ADAMs potential as prognostic and diagnostic markers in cancer treatment is a particularly interesting issue and has great practical significance. There are many new studies concerning ADAMs' roles in carcinogenesis, but there are no recent reviews of the latest developments in this field.

The aim of this systematic review is to analyze the results of studies published on ADAMs in the last 5 years, to present their roles in neoplasm pathogenesis and their potential utility in clinical oncology.
\end{abstract}

Key words: ADAM, cancer, metalloproteases, sheddases

\section{Historical overview}

ADAMs, originally also known as MDC proteins (metalloproteinase/disintegrin/cysteine-rich), were described for the first time in the late 1990's. Their expression and role in regulation of cell biology were confirmed in many different species, from sea squirts to mammals, including humans [1]. Initially, study on ADAMs was limited to determining the role of the protein family in the regulation of reproduction and gamete functionalities, as fertilins (ADAM1 and 2) were involved in the fertilization process [2].

Expression of ADAMs1-5 was found in the testes and their activity affected sperm to egg adhesion and gamete fusion $[3,4]$. ADAMs involvement in regulation of cell-to- cell adhesion and in interactions between the cell and extracellular matrix suggested the potential effect of adamalysines not only in normal physiological processes, but they also provided a basis for considering participation in tumor biology and their ability to invade and metastasize $[5,6]$.

Subsequent scientific reports more and more often confirmed the differential expression of some ADAM proteins between the control of normal tissue and specific types of cancer which theoretically suggests their potential use as diagnostic-prognostic markers. In renal cancer, there was a statistically significant over-expression of ADAM9 in cancerous tissue compared to normal tissue [7]. Further reports confirmed the differential expression of some ADAM proteins between the normal tissues and the specific type of 
cancer. These suggest potential use of ADAMS as diagnostic and prognostic markers.

In pancreatic cancer, ADAM9 expression differed between normal control and cancer and correlated with a lesser degree of differentiation [8]. In the in vitro study of non-small cell lung cancer, the increased expression of ADAM9 positively correlated with a strongly metastatic cell phenotype [9]. The soluble form of ADAM9 protein in cancer tissue seems to promote the invasiveness of cancer. It increase adhesion capacity of cancer cells and regulates the influence of active cancer on the stroma properties which promotes the invasiveness [10].

Many studies suggest the potential of ADAMs as prognostic markers, since overexpression of these proteins has repeatedly been associated with worse prognosis, shorter survival periods and with more malignant biological cancer phenotype [7-9, 11, 12].

One of the processes vital for cancer development is the regulation of the immune response and induced immunological tolerance [13]. The function of ADAMs in the shedding of ectodomains results in the biological activation of numerous cytokines and $\mathrm{CD}$ membrane antigens that are important in the modification of inflammation [14]. In many types of cancers, there was a pathogenetic connection with inflammation which often determines the development of a tumor and has an impact on the course of both disease and prognosis [15]. In some types of inflammatory response, elevated level of certain metalloproteinases was reported [16]. The structure of ADAM proteins includes the adhesive and (for some members) proteolytic domains and some of these proteins are expressed, among others, by human lymphocytes and they can interact with adhesion proteins located on the surface of other leukocytes [17]. The ability of some ADAMs to differentiate immunologically competent cells makes them important in immunological processes [18]. B cells, dendritic cells and various monocyte subpopulations are also able to express these proteins which (according to increasing number of scientific reports) makes ADAMs important in cancer prognosis [19].

The ADAMs' properties mentioned above make them an important object of interest in oncology, especially in relationship to their application in diagnostics as well as in prognosis and monitoring of responses to the applied anticancer treatment.

\section{Current perspectives}

The ADAMs family is currently an object of considerable scientific attention. Due to their role in numerous signaling pathways associated with carcinogenesis, such as PI3K, Notch and TGF- $\beta$ [20-22], research concerning ADAMs often focuses on their role in neoplasm formation and as a potential target of new anticancer therapies [23, 24].

The ADAMs family in humans consists of 20 transmembrane proteins, 12 of which have proteolytic properties. Their functions include ectodomain shedding of membrane

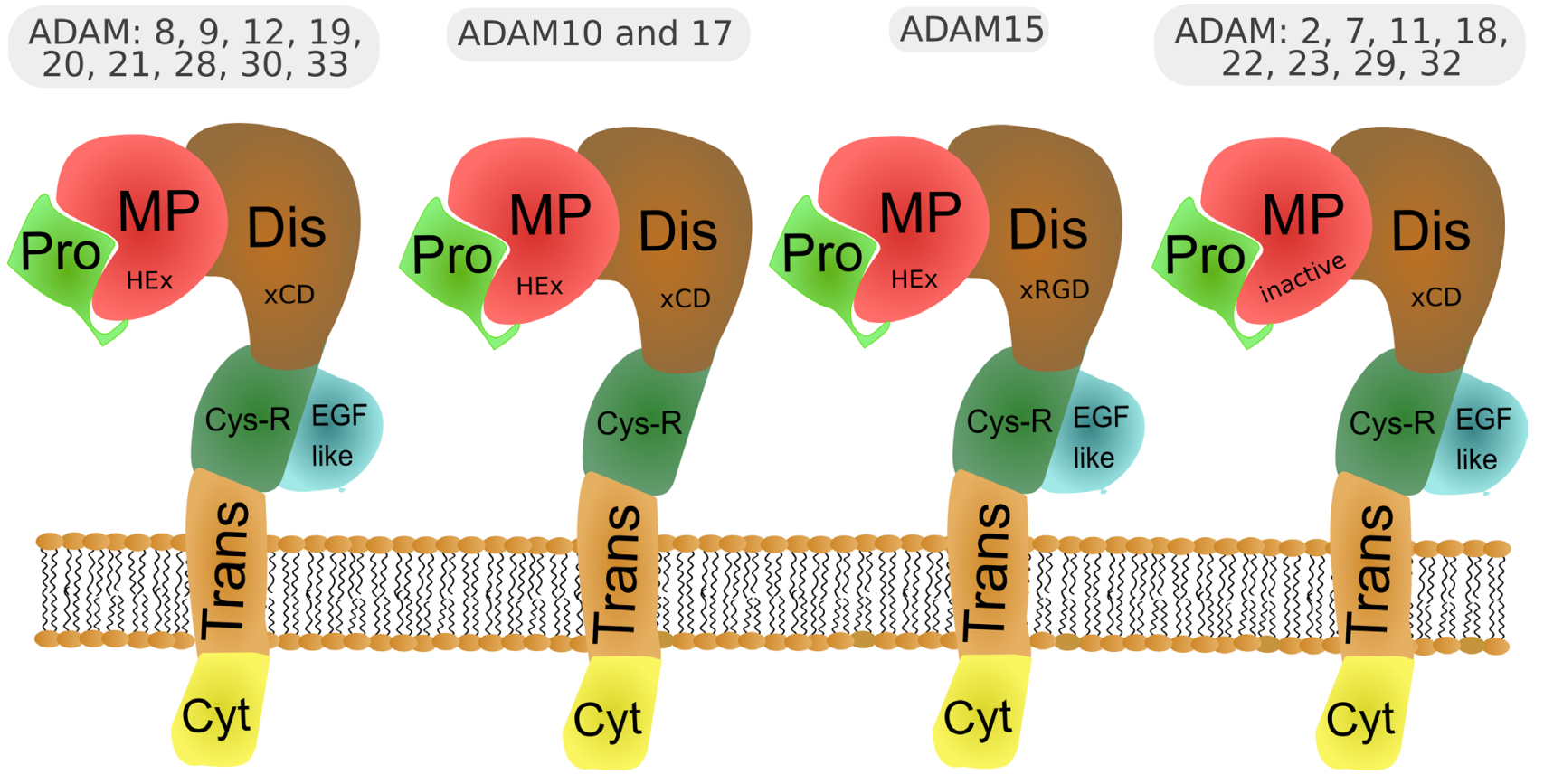

Figure 1. ADAMs general structure. 13 of 20 human ADAM proteins have the consensus sequence HEx (HExGHxxGxxHD) which makes them proteolytically active. Disintegrin domain contains XCD consensus sequence in all, but one family member - ADAM15, which has the RGD sequence. ADAM10 and 17 are missing the EGF-like sequence. 
proteins and integrin binding in interactions between cells and those between cells and the extracellular matrix [1]. Certain family members which have a conservative reprolysin-type domain also have proteolytic properties [25]. ADAMs interact with a variety of substrates, therefore they affect different signaling pathways [26]. They play a role in numerous processes and their ontologies include: regulation of cellular adhesion, sperm-egg interaction, cellular growth, angiogenesis, development of neurons and muscles and modulation of the immune response [27].

The aim of this review is to discuss the results of studies published during the last 5 years concerning the role of ADAMs in neoplasms. The last reviews concerning this topic are over 10 years old and therefore do not describe recent developments in this field [28,29]. The detailed structure and mechanism of action of ADAM metalloproteases was thoroughly described in other studies $[1,26]$ and therefore will not be extensively discussed in this publication. Herein, we present the most important information on this subject.

The ADAM proteins belong to the family also known as adamylasins, which belongs to zinc metalloproteases. ADAMs have a common general structure (Figure 1). The $\mathrm{N}$-terminus of the protein contains a signaling sequence that directs the protein towards the cell membrane and a pro-domain that is responsible for protein folding and enzyme latency. These parts are both cleaved during posttranslational modification in Golgi apparatus (see Figure 2 for more details on ADAMs processing). Then, there is a metalloprotease domain and disintegrin, which interacts with integrins-adhesion molecules. Subsequently, there is a cysteine-rich regulatory domain and an EGF-like domain which occur not only in ADAMs 10 and 17. These are followed by the transmembrane region and a cytoplasmatic tail [1] on the C-terminus.

\section{Role in neoplastic regulation}

Table 1 and Figure 3 present a summary of all studies published during the last 5 years concerning the role of ADAMs in neoplasms. To provide more background of the ADAMs physiological functions, we summarised most of known substrates of proteolytically active ADAMs in Table 2. Table 3 and Figure 4 then summarise the effects of knockout and knock-down in mice. In the subsequent part of this publication the role of ADAMs in particular parts of carcinogenesis is discussed.

\section{Regulation and trafficking of ADAM proteases \\ on the example of ADAM10}

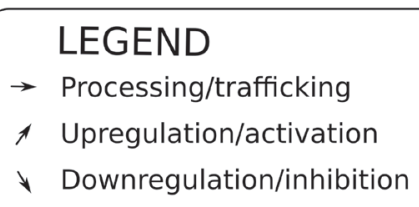

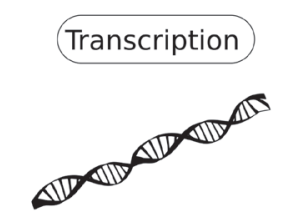

transciption activators

retinoic acid A dihydrotestosterone $A$ SIRT1/RAR-beta 1 PPAR-alpha 1 IL-1/p38/ERK/P1PK $A$ SOX-2 1 and others

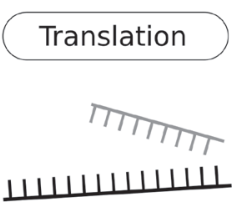

RNA interference

miR122
miR103
miR107
miR1306
miR144
miR451

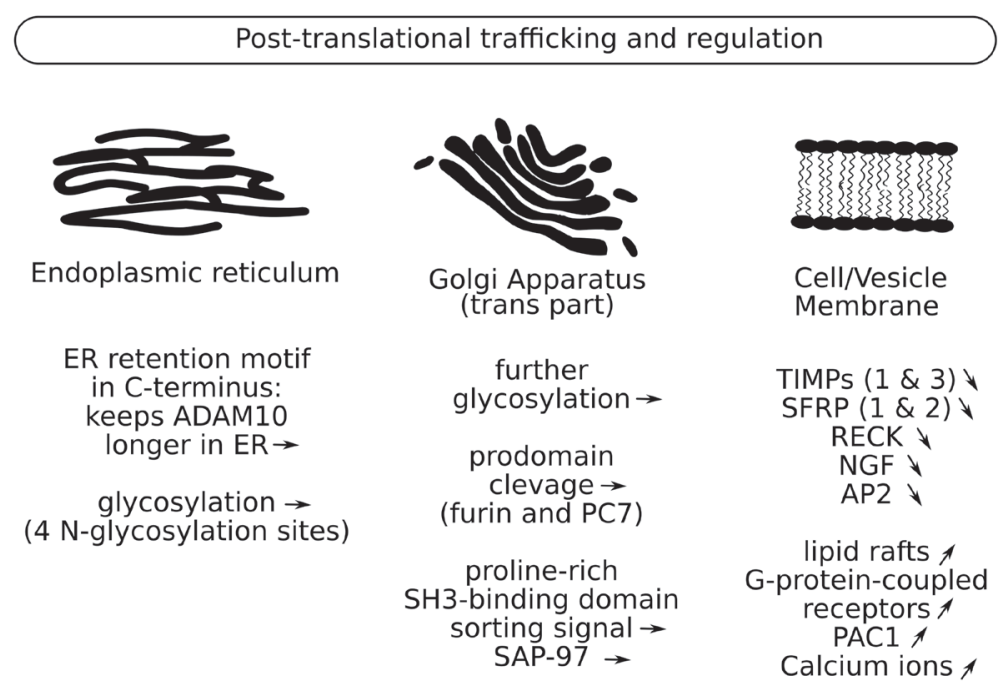

Figure 2. ADAM regulation, processing and trafficking: ADAMs metalloproteases level and activity may be controlled on different levels. Transcription factors can be activated by numerous pathways, different for distinct family members. They are glycosylated in endoplasmic reticulum and in the transpart of Golgi apparatus, cleaved by furin or other protein convertases. ADAM8 and 28 are able to auto-activate. Active proteins are packed in the vesicle which may remain in the cytoplasm or fuse with the cell membrane. Active ADAMs may be inhibited by specific TIMPs, SFRP, RECK. Distinct ADAMs may also have different inhibitors. Localization in the lipid rafts is necessary for activity of some ADAMs. Here, we present the factors processing and regulating the ADAM10 protein, thoroughly described by Vincent [201]. 
Table 1. Current status of role ADAMs in tumorigenesis based on research articles from 2012-2017.

\begin{tabular}{|c|c|c|c|c|c|}
\hline Name & Synonyms & Overexpressing tumors or sites & Role \& traits in tumors & Type of study & Other \\
\hline ADAM8 & $\begin{array}{l}\text { CD156, CD156a, } \\
\text { MS2 }\end{array}$ & $\begin{array}{l}\text { Osteosarcoma [72], pancreas } \\
{[42,93] \text {, breast [94], head and }} \\
\text { neck [95] }\end{array}$ & $\begin{array}{l}\text { tumor growth }[42,72,94] \text {, } \\
\text { metastasis }[42,93,94], \\
\text { angiogenesis }[94]\end{array}$ & $\begin{array}{l}\text { In vitro }[42,93,94] \\
\text { In vivo }[42] \\
\text { Clinical }[72,94,95]\end{array}$ & $\begin{array}{l}\text { Elevated serum } \\
\text { level in breast ca. } \\
{[94]}\end{array}$ \\
\hline ADAM9 & $\begin{array}{l}\text { KIAA0021, MCMP, } \\
\text { MDC9, meltrin } \\
\text { gamma, Mltng }\end{array}$ & $\begin{array}{l}\text { NSCLC }[51] \text {, glioma }[84,96,97] \text {, } \\
\text { breast }[98,99], \text { prostate }[100] \\
\text { colon }[101], \text { pancreas }[102]\end{array}$ & $\begin{array}{l}\text { Promotion of survival } \\
{[51,97] \text {, growth }[99,100] \text {, }} \\
\text { metastasis }[51,96-102] \text {, } \\
\text { osteolysis }[100]\end{array}$ & $\begin{array}{l}\text { In vitro }[51,96,98-102] \\
\text { in vivo }[99,100] \\
\text { Clinical }[84,99,101,102]\end{array}$ & \\
\hline ADAM10 & $\begin{array}{l}\text { CD156c, } \\
\text { HsT18717, kuz, } \\
\text { MADM }\end{array}$ & $\begin{array}{l}\text { Lymphoma [103], esophagus } \\
\text { [104] colorectal [105], uveal mel- } \\
\text { anoma [106], pancreas [107,108], } \\
\text { breast }[21,109,110] \text {, glioblastoma } \\
{[111,112] \text {, nasopharyngeal }[81] \text {, }} \\
\text { hepatocellular [113,114] } \\
\text { tongue [115], } \\
\text { bladder [82], oral }[116], \text { pituitary } \\
\text { gland [85], NSCLC [117] }\end{array}$ & $\begin{array}{l}\text { Immune evasion } \\
{[103,104,109,110,112,114],} \\
\text { chemoresistance } \\
{[82,105,112,114], \text { growth }} \\
{[81,105,107,113], \text { metastasis }} \\
{[21,81,85,106,107,113,115-} \\
117]\end{array}$ & $\begin{array}{l}\text { In vitro: }[21,81,82,85,103- \\
105,107,108,110,112,115- \\
117], \\
\text { In vivo }[105,114] \\
\text { Clinical: } \\
{[81,82,85,103,104,106,108-} \\
111,113,114,116,117]\end{array}$ & $\begin{array}{l}\text { Elevates serum } \\
\text { level of Fat1 in } \\
\text { pancreatic ca. } \\
{[108]}\end{array}$ \\
\hline ADAM12 & $\begin{array}{l}\text { MCMPMltna, mel- } \\
\text { trin alpha, MLTN }\end{array}$ & $\begin{array}{l}\text { skin cancer [118], ovarian } \\
\text { carcinoma [89], SCLC [119], } \\
\text { osteosarcoma [120], melanoma } \\
\text { [121], breast [73] }\end{array}$ & $\begin{array}{l}\text { metastasis }[118,119], \\
\text { growth [119], osteolysis } \\
{[120] \text {, angiogenesis }[73]}\end{array}$ & $\begin{array}{l}\text { In vitro }[73,89,118-120] \\
\text { In vivo }[118,120] \\
\text { Clinical }[73,89,118,119,121]\end{array}$ & $\begin{array}{l}\text { Elevated urinary } \\
\text { level in gastric } \\
\text { cancer [122], } \\
\text { SCLC [119], se- } \\
\text { rum - in ovarian } \\
\text { ca. [89] }\end{array}$ \\
\hline ADAM15 & $\begin{array}{l}\text { MDC15, metar- } \\
\text { gidin }\end{array}$ & NSCLC [123] & metastasis [123] & $\begin{array}{l}\text { In vitro }[123] \\
\text { Clinical }[123]\end{array}$ & \\
\hline ADAM17 & CD156B, cSVP & $\begin{array}{l}\text { glioblastoma [112], melanoma } \\
{[121], \text { colon }[124], \text { gastric }[125]} \\
\text { ovary [22], prostate }[126]\end{array}$ & $\begin{array}{l}\text { tumor growth }[22,124] \text {, } \\
\text { metastasis }[124,126] \\
\text { immune evasion [112], } \\
\text { chemoresistance [112], }\end{array}$ & $\begin{array}{l}\text { In vitro }[22,11,124,126] \\
\text { clinical }[12,125]\end{array}$ & \\
\hline ADAM22 & $\begin{array}{l}\text { MDC2, metallo- } \\
\text { proteinase-like, } \\
\text { disintegrin-like, } \\
\text { and cysteine-rich } \\
\text { protein } 2\end{array}$ & breast [127] & $\begin{array}{l}\text { chemoresistance [127], } \\
\text { metastasis [127] }\end{array}$ & $\begin{array}{l}\text { in vitro }[127] \\
\text { in vivo }[127]\end{array}$ & \\
\hline ADAM28 & $\begin{array}{l}\text { ADAM23, eM- } \\
\text { DCII, MDC-Lm, } \\
\text { MDC-Ls }\end{array}$ & $\begin{array}{l}\text { B-cell leukemia }[128,129], \text { lung } \\
{[130], \text { breast }[130], \text { kidney }[130] \text {, }} \\
\text { NSCLC }[131]\end{array}$ & $\begin{array}{l}\text { tumor growth }[131] \\
\text { Metastasis }[128,130,131] \\
\text { survival }[130]\end{array}$ & $\begin{array}{l}\text { In vitro }[130] \\
\text { In vivo }[130] \\
\text { Clinical }[128,129,131] \text {, }\end{array}$ & $\begin{array}{l}\text { Elevated in serum } \\
\text { in NSCLC [131], } \\
\text { Elevated CD200 } \\
\text { serum level in } \\
\text { B-CLL [129] }\end{array}$ \\
\hline ADAM29 & $\begin{array}{l}\text { cancer/testis } \\
\text { antigen } 73, \text { CT73, } \\
\text { svph1 }\end{array}$ & Breast [132] & $\begin{array}{l}\text { tumor growth [132], } \\
\text { metastasis [132] }\end{array}$ & $\begin{array}{l}\text { In vitro }[132] \text {, } \\
\text { clinical }[132]\end{array}$ & \\
\hline ADAM33 & $\begin{array}{l}\text { dJ964F7.1, DK- } \\
\text { FZp434K0521 }\end{array}$ & laryngeal, sinonasal region [74]. & $\begin{array}{l}\text { Promotion of angiogenesis } \\
{[74]}\end{array}$ & Clinical [74] & \\
\hline
\end{tabular}

\section{Tumor growth and survival}

The signaling pathway of the PI3K kinase is a significant part of carcinogenesis when it comes to the regulation of the cell cycle and cellular differentiation [30, 31]. In hepatocellular carcinoma a lower expression of ADAM10 induced apoptosis of neoplastic cells and decreased the proliferation index which was correlated with decreased phosphorylation of Akt and PI3K [32].

\section{Metastasis}

Adhesion proteins and cell junctions stabilize tissues, thus determining their normal function and structure. Carcinogenesis may be a result of a disruption of this homeostasis due to the changes in gene expression which in turn leads to cell differentiation, neoplastic progression and metastasis [33]. Loss of adherens junctions alters the properties and polarity of cells which determine changed expression of 
Table 2. ADAMs confirmed substrates. Metalloproteases function is determined by their substrates. Here, we present a summarized list of most important confirmed substrates of distinct ADAMs. Most were presented in previous reviews [26, 70]. Here, we present a table of ADAM substrates summarized in mentioned papers with recently discovered protein substrates. Notably, ADAM10 and 17 have the broadest range of confirmed substrates. Most probably, there are many more undiscovered substrates; recent secretome protein identification revealed 91 highly probable substrates of ADAM10 [133], although these need to be confirmed in more detailed studies.

\begin{tabular}{|c|c|}
\hline ADAM & Substrates \\
\hline ADAM8 & $\begin{array}{l}\text { ADAM } 8 \text { prodomain, APP, CD23, CD153, CHL1, L-selectin, MBP [26,70], TNFR-1 [134], CD31, Flk-1, Flt-1, Tie-2, EphrinB2 and B4, } \\
\text { KL1, E-selectin, neuregulin-1ß2, VE-cadherin [135] fibronectin [136] }\end{array}$ \\
\hline ADAM9 & $\begin{array}{l}\text { ADAM10, APP, collagen XVII, DLL1, EGF, FGFR2IIIB, HB-EGF, IGFBP5, insulin-B chain, KL1, Laminin, p75 neurotrophin receptor } \\
\text { [26,70], elastin, entactin, fibronectin [137], CD40, EphB4, Flk-1, Tie-2, VCAM, VE-cadherin [138], }\end{array}$ \\
\hline ADAM10 & $\begin{array}{l}\text { APP, Axl, betacellulin, cadherin gamma C3 and B4, CD23, CD30, CD44, c-Met, collagen IV and XVII, CX3CL1, CXCL16, Desmoglein-2, } \\
\text { DLL1, E-cadherin, EGF, Ephrin A2 and A5, FasL, HER2, IL6R, Klotho, L1-CAM, LAG-3, MICA, Notch, N-cadherin, PCDH-Gamma C3/ } \\
\text { B4, prion protein, RANKL, TSHR, VE-cadherin [26,70], GPVI [139] }\end{array}$ \\
\hline ADAM12 & $\begin{array}{l}\text { collagen IV, DLL1, fibronectin, gelantin, HB-EGF, IGFBP3, IGFBP5, transferrin [26,70], E-cadherin [140], Flk-1, Kitl1, Tie-2, VCAM-1, } \\
\text { VE-Cadherin [73] }\end{array}$ \\
\hline ADAM15 & $\begin{array}{l}\text { amphiregulin, HB-EGF, CD23, E-cadherin, collagen IV, ADAM10 [26,70] desmoglein, TGF-B, epiregulin, betacellulin, Notch, [141] } \\
\text { FGFR2IIIb [142], N-cadherin [143] }\end{array}$ \\
\hline ADAM17 & $\begin{array}{l}\text { ACE2, ALCAM, amphiregulin, APP, CD30, CD40, CD44, collagen XVII, CSF-1, CX3CL1, DLL1, desmoglein, epigen, epiregulin, Growth } \\
\text { hormone receptor, HB-EGF, HER4, ICAM-1, IL1R, IL6R, KL-1, Klotho, L1-CAM, LAG-3, L-selectin, MHC-class I-related chain A/B, } \\
\text { N-CAM, Nectin 4, Neuregulin 1, Notch-1, NPR, P55 TNF Receptor, p75NTR, PTP-LAR, Pref-1, PrPc, RANKL, Semaphorin 4D, TGF-A, } \\
\text { TrkA, TNF-A, TNF receptor I and II, VCAM-1, Vps10-p [26,70] betacellulin, c-kit, IL15RA, M-CSFR, NGFR, JAM-A, Meprin-B, Jagged, } \\
\text { Mucin-1 [144] GPVI [139] }\end{array}$ \\
\hline ADAM19 & ADAM19, neuregulin, RANKL, TNFA, [26,70], PRR [145] \\
\hline ADAM20 & No substrates reported \\
\hline ADAM21 & No substrates reported \\
\hline ADAM28 & CD23, CTGF, IGFBP-3, MPB, [146], CD200, TNF-alpha, von Willebrand factor, [147] \\
\hline ADAM30 & cathepsin D, GKAP1, IRS4, [148] \\
\hline ADAM33 & CD23KITLG, \\
\hline
\end{tabular}

certain proteins and response to growth factors in the extracellular matrix [34-36].

The cell surface glycoprotein CUB domain-containing protein 1 (CDCP1) is a transmembrane protein, the active form of which is over-expressed in various types of cancer [37]. In lung cancer the expression of CDCP1 is correlated with the expression of the ADAM9 metalloproteinase which facilitates metastasis [38]. The ADAM-9 metalloprotease affects the adhesive properties of prostate cancer cells. It is considered a pro-adhesive marker of the extracellular matrix which has an affinity for certain membrane integrins (alpha 6 beta 1 integrin), and in some cases its elevated concentration inhibits the adhesion to laminin [39]. The overexpression of integrin alpha 6 beta 1 is a common finding in neoplasms [40] and is correlated with metastasis and cancer cell invasion [41].

In pancreatic cancer, the process of neoplastic migration and invasion was shown to be correlated with the expression of ADAM8 which regulates the activity of MMP-2 metalloproteinase by influencing the ERK1/2 kinase and the EGF/ EGFR signaling pathway [42]. The expression of ADAM8 was reported to be significantly higher in colorectal cancer than in healthy tissues, and was correlated with poorer prognosis and faster recurrence [43]. Silencing of MMP-2 expression in colorectal cancer cell lines resulted in limited cell migration [44]. The CD44 membrane glycoprotein and c-met kinase seem to be the key factors in regulating the migration and

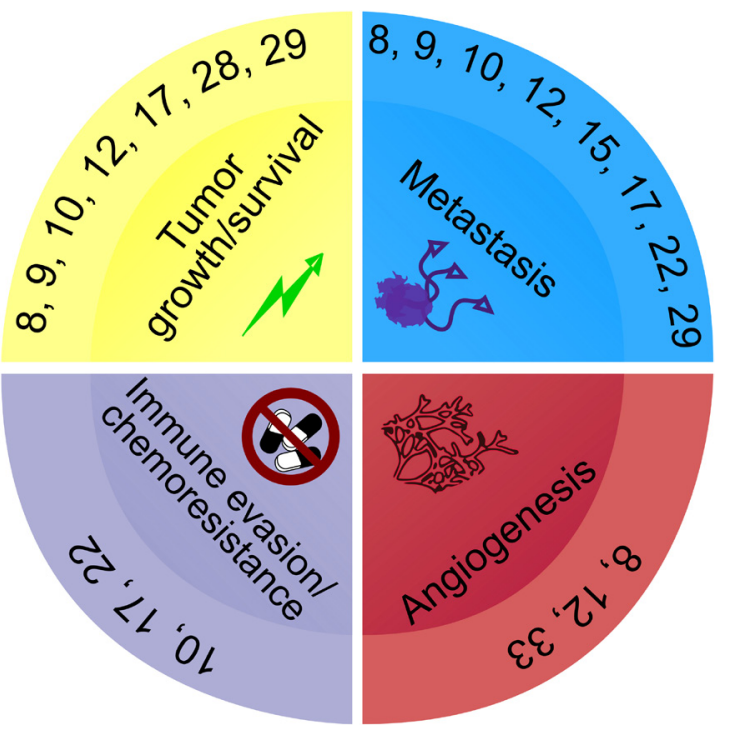

Figure 3. ADAMs most popular functions in cancer. Numbers indicate the numbers of ADAMs family members, which were proved to play roles in specific aspects of cancer. For more details, see Table 1.

invasion of neoplastic cells $[45,46]$. ADAM8 increases the expression of the phosphorylated form of Akt (pAkt) and phosphorylated extracellular-regulated kinase $1 / 2(\mathrm{pErk} 1 / 2)$, thus affecting CD44 and c-met [20]. 


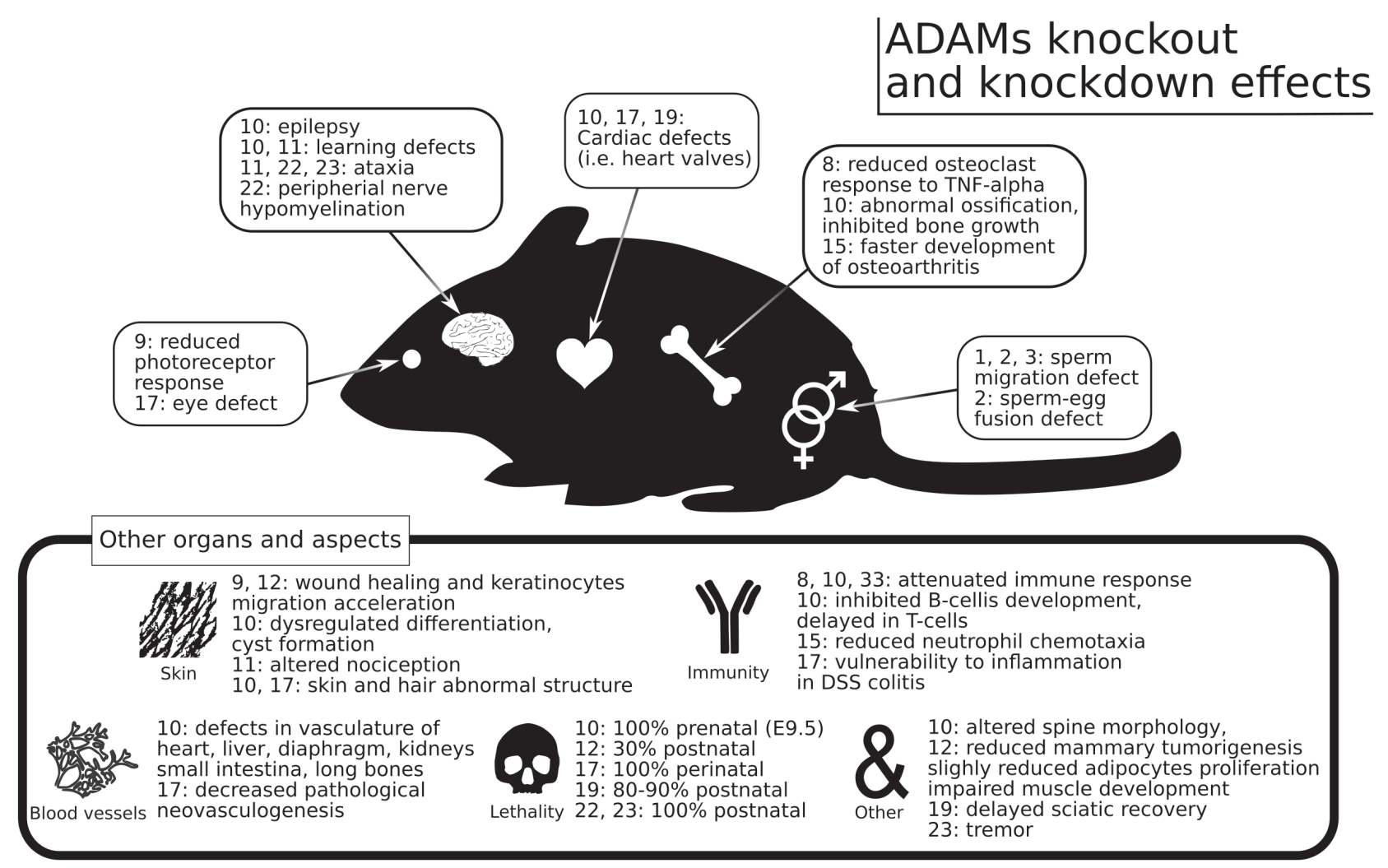

Figure 4. ADAM knock-outs and knock-down in mice. This figure presents the effects summarized in Table 3.

\section{Immune evasion}

Chronic inflammation is an important cause of carcinogenesis. Exogenous factors are responsible for most cases of certain types of cancer [47]. For some diseases characterized by local chronic inflammation (inflammatory bowel diseases and gastritis), there is a higher incidence of particular types of neoplasms [48]. Numerous proinflammatory cytokines are over-expressed in neoplastic cells and activate STAT family transcription factors, thus regulating cell division and differentiation [49]. In pancreatic cancer, the JAK/STAT pathway, through the activated STAT3 factor, led to the expression of the PD-L1 gene which is responsible for T lymphocyte regulation [50]. There was additive influence of the inhibition of STAT3 transcription factor and ADAM9 in non-small cell lung cancer on reducing the proliferation index and increasing the proportion of cells undergoing apoptosis. Silencing the expression of these two factors led to higher activity of initiator caspases 3, 8 and 9. This not only induced apoptosis, but also limited the cell invasion and migration [51].

The ADAM8 metalloprotease regulates the expression of cytokines by its influence on the T-helper type 2 cells (Th2) which in turn induces and exacerbates local inflam- mation [52]. The activation of the Notch signaling pathway in epithelial cells by ADAM10 through the Hes1 and Hey1 factors results in release of proinflammatory interleukin-6 [53]. The increased activity of IL- 6 seems to be dependent on the proteolytic activity of the ADAM10 and ADAM17 proteins which affect availability of the soluble form of the IL-6 receptor [54]. Chronic inflammation leads to the remodeling of epithelium and its dedifferentiation which is a common occurrence in the NF-kB pathway regulated by cytokines [55].

Some metalloproteases also decrease the susceptibility of neoplasms to cytotoxic lymphocytes and phagocytes. Glioma-derived cells produce ADAM10 which has immunosuppressive properties to $\mathrm{CD}^{+} \mathrm{B}$ cells - the main defense of the immune system. ADAM10 forces activated B cells to differentiate into regulatory $B$ cells and TGF-B also plays an important role in this mechanism of immunosuppression [56]. The activation of PI3K in endothelial cells by ADAM10 may also induce inflammation through the Notch signaling pathway and activation of gamma secretase, thus leading to increased expression of interleukin-6 [57]. The over-expression of pro-inflammatory cytokines is a common finding in many different types of cancer $[53,58]$. 
Table 3. Gene knock-out/knock-down effect in mice. Gene knock-out in mouse models allows us to recognize the most pronounced functions of downregulated protein. In case of ADAM10 and 17, knock-downs and conditional knock-outs mice were also studied, as classical knock-out mutations are lethal. Most of the effects were summarized in previous reviews $[26,70,149]$, there were only a few new discovered in the last 5 years. ADAM1 and 3 proteins are absent in humans (only as pseudogenes).

\begin{tabular}{|c|c|}
\hline ADAM & Gene knock-out effect in mice \\
\hline ADAM1 & Sperm migration defect [150] \\
\hline ADAM2 & Sperm migration and egg fertilization defect $[151,152]$ \\
\hline ADAM3 & Sperm migration defect $[153,154]$, \\
\hline ADAM8 & No major pathologies [155]. Reduced osteoclast response to TNF-A [156], attenuated immune response $[157,158]$ \\
\hline ADAM9 & $\begin{array}{l}\text { No major pathologies [159]. Reduced photoreceptor responses, retinal degeneration in older individuals (20 months) [160]; wound heal- } \\
\text { ing acceleration, increased keratynocyte migration [161] }\end{array}$ \\
\hline ADAM10 & $\begin{array}{l}\text { Systemic knock-out: prenatal death at E9.5 [162]. Knock-out in endothelial cells: defects in the vasculature of the heart, liver, diaphragm, } \\
\text { kidneys, small intestine, long bones; abnormal endochondral ossification, inhibited long bone growth, pathologic neovascularization } \\
\text { after induced retinopathy [163,164]. Postnatal knock-out in brain: epileptic seizures, learning deficits, altered spine morphology, defective } \\
\text { synaptic functions [165], aberrant neuronal migration, disorganized laminar architecture [166]. Postnatal epidermal knock-out: dysregu- } \\
\text { lation of epithelial differentiation, barrier function loss of hair, malformed vibrissae, hyperproliferation, cyst formation, thymic atrophy } \\
\text { [167,168]. B-cell knock-out: diminished immune response [169]. Lymphoid and myeloid knock-out: no B cell development, delayed T cell } \\
\text { development, systemic expansion of myeloid-derived suppressor cells [170]. }\end{array}$ \\
\hline ADAM11 & No major pathologies, altered nociceptive response [171] impaired spatial learning and motor coordination [172] \\
\hline ADAM12 & $\begin{array}{l}\text { 30\% postnatal lethality [173], reduced mammary tumorigenesis [174], increased keratynocyte migration [175] slightly reduced adipocytes } \\
\text { proliferation [173,176], impaired muscle development [173]. }\end{array}$ \\
\hline ADAM15 & $\begin{array}{l}\text { No major pathologies. Reduced neutrophil chemotactic transmigration across, attenuated pulmonary inflammatory response [177], faster } \\
\text { development of osteoarthritis [178] }\end{array}$ \\
\hline ADAM17 & $\begin{array}{l}\text { Knock-out: Perinatal lethality [162], eyelid, hair, skin, lung development and heart valves defects [179,180]. Gene knock-down: eye, heart, } \\
\text { skin defects, increased vulnerability to inflammation in DSS colitis [181]. Endothelial/smooth muscle knock-out: decreased pathological } \\
\text { neovascularization [182]. }\end{array}$ \\
\hline ADAM19 & Cardiac defects, high postnatal lethality (80-90\%) [183-185]. Delayed sciatic recovery after nerve crush, delayed remyelination [186] \\
\hline ADAM22 & Postnatal lethality, ataxia and peripheral nerve hypomyelination $[187,188]$ \\
\hline ADAM23 & Postnatal lethality (before 14 day), tremor, ataxia [189] \\
\hline ADAM33 & No major pathologies [190]. Remodeling and inflammation of lung suppressed even after allergen challenge [191] \\
\hline
\end{tabular}

Table 4. Chemoresistance mechanisms of ADAM proteins.

\begin{tabular}{|c|c|c|c|c|}
\hline Drug & Protein & Chemoresistance associated process & Type of tumor & References \\
\hline Trastuzumab & ADAM10 & $\begin{array}{l}\text { Higher ADAM10 concentration by protein kinase B inhibi- } \\
\text { tion; shedding of HER3, releasing HER- } 3 \text { bound heregulin, } \\
\text { forming trastuzumab resistant HER- } 2 / 3 \text { heterodimers. }\end{array}$ & $\begin{array}{l}\text { HER2 positive breast and } \\
\text { esophageal cancer }\end{array}$ & $\begin{array}{l}{[192]} \\
{[110]}\end{array}$ \\
\hline Gemcitabine & ADAM10 & Shedding of Amyloid Precursor Protein (APP) to sAPPa & Pancreatic cancer & {$[107,193]$} \\
\hline Temozolomide & ADAM8 & Activation of pERK1/2 and/or pAkt. & Glioblastoma & [194] \\
\hline Fluorouracil & ADAM9 & $\begin{array}{l}\text { Downregulation of miR-20b elevates the expression of } \\
\text { ADAM9 and EGFR }\end{array}$ & Colorectal cancer & [195] \\
\hline Fluorouracil & ADAM17 & $\begin{array}{l}\text { Maintaining stem cell phenotype of cancer cells, cleavage of } \\
\text { Notch1, Jagged-1 and Jagged-2 }\end{array}$ & Colorectal cancer & [196] \\
\hline Doxorubicin & ADAM10 & Activation of the PI3-K/Akt pathway & Hepatocellular carcinoma & [197] \\
\hline Fluorouracil, oxaliplatin & $\begin{array}{l}\text { ADAM10 } \\
\text { ADAM17 }\end{array}$ & $\begin{array}{l}\text { Higher rate of glycolysis, promoting the epithelial-mesen- } \\
\text { chymal transition of cancer cells }\end{array}$ & Colorectal cancer & [198] \\
\hline Selumetinib (AZD6244) & ADAM17 & JAK1/2-dependent activation of STAT3, c-met & KRASMT colorectal cancer & [199] \\
\hline Cisplatin & ADAM17 & Hypoxia $\rightarrow$ activation of EGFR/PI3K/Akt pathway & Hepatocellular carcinoma & [200] \\
\hline
\end{tabular}

\section{Chemoresistance}

In spite of considerable progress, anti-cancer treatment has numerous long-term side effects [59]. Chemotherapy is one of the most commonly used methods, either on its own or with other treatment modalities, but it has many serious side effects and leads to complications [60]. Due to the constantly increasing incidence of neoplasms, these side effects and unsatisfying efficacy of currently used treatment regimens will continue to be an increasing financial burden for healthcare systems [61]. Unfortunately, more money spent on anti-cancer drugs does not reflect their efficacy [62]. The diverse molecular properties of neoplasms and various types of defense mechanisms of cancer cells against intro- 
duced treatment modalities are significant problems that decrease the efficacy of chemotherapy [63-65].

The activation by ADAMs of particular signaling pathways and regulation of protein expression may be potential important causes of chemo-resistance to currently used chemotherapeutic agents (Table 4).

\section{Angiogenesis}

During the development of neoplasm, new thin-walled blood vessels are formed on the base of an already existing vascular bed. Angiogenesis occurs in the early stages of carcinogenesis. It is complex process with multiple stages that allows progression and growth [66]. Among many neo-angiogenesis models proposed, endothelial cellsprouting remains one of the most popular and described models. It assumes progressive growth and ramification of existing vessels towards an avascular zone [67].

The initiating factors show significant importance in tumor angiogenesis. One of these is the Delta-like 1 (DLL1) - ligand of Notch. Most notably, it activates proliferation motility of endothelial cell, therefore contributing significantly to angiogenesis [68]. This ligand can be activated by some ADAM proteases $(9 / 12 / 17)$ which in turn activates Notch signaling pathway [69]. Notch itself is a substrate of ADAM 10/15/17 [70]. The activation of Notch in vascular endothelial cells is a potent inducer of angiogenesis [68].

Regulation of neo-vascularization by ADAM proteases also results from the effects on known inhibitors of angiogenesis. Endostatin is a globular protein belonging to strong endogenous inhibitors of the formation of new blood vessels [71]. Although endostatin is not a confirmed substrate of any ADAM, its expression in primary osteosarcoma was linked with ADAM8 in tumor level, and both proteins were positively correlated with tumor size, stage and distant metastasis [72].

Some of the metalloproteinases are characterized by increased expression in the tumor vascular bed. In the vasculature of infiltrating ductal breast carcinoma, ADAM12 showed a tendency to over-expression compared to normal tissue. This may be caused by increased production of metalloproteinase, induced by cytokine secreted by tumor cells. The promotion of neo-vascularization by ADAM12 most likely results from shedding of adhesion molecules and proangiogenic receptors [73]. Similar relationship was found for ADAM33 in laryngeal cancer; there protein was localized predominantly intracellularly and in tumor vasculature [74].

Although the aforementioned Notch signaling modulation by ADAMs plays an important role in the initiation of sprouting angiogenesis, these metalloproteases influence other proteins involved in this process. Knockdown of ADAM17 (Notch sheddase) develops a different blood vessel phenotype than seen in Notch knockout mice. Inhibition of ADAM17 (but not ADAM10) induced the expression of a Thrombospondin 1 - inhibitor of angiogenesis [75].
These results indicate that determining the importance of ADAM proteins in the regulation of tumor-induced neo-vascularization requires further study.

\section{ADAMs as diagnostic and prognostic markers}

The Ki67 proliferation index is widely used to assess the grade of tumor histological malignancy. This is correlated with cancer patient cell proliferation, time to recurrence and shorter survival rate [76]. Ki67 and the histological tumor grade are also correlated with changes in phenotype of lymph node metastases compared to the primary tumor, together with certain molecular markers associated with malignancy and a poorer prognosis [77].

Tumor cyto-architectonics is not the only example of trait corresponding with expression of certain proliferation markers. The Ki67 proliferation index seems to be commonly approved as a factor correlating with the clinical staging and survival curves, however its utility has been questioned [78, 79]. The heterogeneity of molecular markers in neoplasms is certainly not limited to several proteins and its complexity indicates that new potential diagnostic and prognostic markers must be searched for.

ADAM sheddases could be such potential markers. There has been increasing recent data linking ADAMs with neoplastic progression, grading and TNM staging in certain neoplasms.

\section{Oral squamous cell carcinoma}

The expression of ADAM10 is dependent on staging and correlates with the tumor diameter expressed in TNM classification. Patients with more advanced disease had lower expression of ADAM10 than both the control group and patients with less advanced disease. Interestingly, there was a similar level of ADAM10 expression in the latter two groups. Moreover, the expression of ADAM10 seems to be dependent on sex: it is significantly lower in males than in females [80].

\section{Nasopharyngeal cancer}

The expression of ADAM10 is also elevated in nasopharyngeal cancer where it is correlated with clinical stage ( $\mathrm{pT}$ parameter of TNM classification). The increased expression of ADAM10 also decreases survival rates in these patients [81].

\section{Bladder cancer}

There is a positive correlation between ADAM10 expression and tumor grade (G1 versus G2-G3) [82].

\section{Brain tumors}

The expression of ADAM10 mRNA is higher for more malignant glial tumors. ADAM10 has mainly been reported 
in cell membranes and blood vessel walls. In high-grade gliomas, the ADAM10 expression is significantly higher than in grade I/II gliomas and in the control group [83]. Similar findings were reported for ADAM9. The expression of this sheddase in gliomas was found to be dependent on tumor histological grading; for instance, the expression of ADAM9 in glioblastoma is significantly higher than in less malignant gliomas. It is also associated with poorer prognosis. In malignant astrocytic tumors, it is higher than in oligodendroglioma - therefore, the expression depends on tumor type [84]. ADAM10 is over-expressed in many neoplasms, including pituitary adenoma. In vitro and in vivo research conducted by Pan et al. shows that invasion and cleavage of CD44 and L1 are correlated with ADAM10 expression. The expression of ADAM10 is increased in high-grade pituitary adenomas compared to low-grade adenomas and healthy pituitary glands. The elevated CD44 and L1 cleavage is regulated by ADAM10 through calcium cellular signal (CD44), Src and ERK1/2 (L1). ADAM10 inhibitors may block cell migration mediated by L1 and decrease CD44-dependent cell migration and invasion. Pituitary adenoma is another neoplasm where ADAM10 could be a potential target for clinical therapy [85]. ADAM12 was found to be up-regulated in human pituitary adenomas with cavernous sinus invasion compared to non-invasive adenomas. Additionally, there is a positive correlation between ADAM12L isoform and the Ki-67 proliferation index. In vitro experiments showed that ADAM12 silencing inhibited cell invasion and migration and even suppressed cell proliferation. ADAM12 could therefore be a therapeutic target in pituitary adenomas to determine disease severity [86].

\section{Thyroid cancer}

Xiong et al. concluded that miRNA-126-3p plays a suppressive role in thyroid cancer cells. Lower expression of miRNA-126-3p was observed in larger primary tumors and in cases with extrathyroidal invasion and high-risk groups for recurrent thyroid cancer. It was also found to be significantly lower in thyroid cancer than in follicular adenomas. On the other hand, the overexpression of miRNA-126-3p was reported to inhibit thyroid cancer cell proliferation, spheroid formation, migration, VGF secretion and lung metastasis in vivo. The authors determined that the two direct targets of miRNA-126-3p are SLC7A5 and ADAM9. This suggests that these genes, in particular, mediate the suppressive effects of miRNA-126-3p [87].

ADAM17 and ADAM10 take part in the Notch signaling pathway as a second receptor cleavage. The third receptor cleavage is gamma-secretase. Available data suggests that in papillary thyroid cancer MAML2, MAML3, JAG1 and Notch1 (members of the Notch family) are up-regulated. Monoclonal antibodies targeting Notch receptors or Notch ligands, as well as $\gamma$-secretase inhibitors (GSI), are potential drugs for various solid tumors. Some antibodies and GSIs are in early clinical trials; however, further studies are necessary [88].

\section{Ovarian carcinoma}

ADAM12 has been investigated as a prognostic factor in ovarian carcinoma. The expression of this metalloproteinase is low in healthy tissues, but increases in certain types of cancer. Cheon et al. proved that high serum protein levels of ADAM12 and ADAM12 mRNA are associated with poor survival in patients with high-grade serous ovarian carcinoma. The high expression of ADAM12 mRNA is correlated with lymphatic and vascular tumor invasion and the residual tumor after cyto-reduction. These authors suggest that tumors which produce high levels of ADAM12 are more aggressive [89].

Lee et al. [90] first demonstrated that ADAM15 is secreted as an exosomal component and they suggested ADAM15-rich exosomes as potential tumor inhibitors. According to the results of subsequent studies, the ADAM15 ectodomain is shed from secretory exosomes and can suppress vitronectin-induced cancer cell migration and MEK/ERK signaling pathway activation. On the other hand, shedding of the ADAM15 ectodomain was induced after incubation with human ovarian carcinoma cell line MDAH2774, and this process was associated with serine protease activity [90].

ADAM17 was suggested as a potential immunotherapeutic target due to its ability to control angiogenesis and cellular proliferation and migration [91]. Richards et al. tested cell lines with specific anti-human ADAM17 IgG antibody and pituitary clone D1. D1(A12) was found to inhibit the proteolysis of ADAM17 substrates, particularly that of TNF- $\alpha$, and the in vitro effect was dose-dependent. In contrast, TNF-a shedding in vivo was similar to the control group - mice without D1(A12) treatment. Although ADAM17 was considered to play a crucial role in shedding TNF- $\alpha$, other ADAMs most likely take over the role of ADAM17 in vivo. Investigators suggested that the simultaneous inhibition of ADAM17, ADAM 10 and ADAM19 might be required to stop TNF-a shedding in vivo [22]. On the other hand, epigenetic repression of ADAM19 due to impaired SMAD4 nuclear translocation, as in the TGF- $\beta$ signaling pathway, may contribute to ovarian cancer progression [92].

\section{Conclusions}

ADAMs provide a promising field of research in contemporary oncology. Their role in the pathogenesis of neoplasms and their potential clinical utility as diagnostic and prognostic markers is reflected in the constantly increasing number of studies with ADAMs. However, further studies are required to elucidate the precise functions of ADAMs and to establish their potential clinical applications. 


\section{References}

[1] GIEBELER N, ZIGRINO P. A disintegrin and metalloprotease (ADAM): Historical overview of their functions. Toxins (Basel) 2016; 8. https://doi.org/10.3390/toxins8040122

[2] WATERS SI, WHITE JM. Biochemical and molecular characterization of bovine fertilin alpha and beta (ADAM 1 and ADAM 2): a candidate sperm-egg binding/fusion complex. Biol Reprod 1997; 56: 1245-1254. https://doi.org/10.1095/ biolreprod56.5.1245

[3] YUAN R, PRIMAKOFF P, MYLES DG. A role for the disintegrin domain of cyritestin, a sperm surface protein belonging to the ADAM family, in mouse sperm-egg plasma membrane adhesion and fusion. J Cell Biol 1997; 137: 105-112

[4] EVANS JP, SCHULTZ RM, KOPF GS. Mouse sperm-egg plasma membrane interactions: analysis of roles of egg integrins and the mouse sperm homologue of $\mathrm{PH}-30$ (fertilin) beta. J Cell Sci 1995; 108 (Pt 10): 3267-3278

[5] WOLFSBERG TG, STRAIGHT PD, GERENA RL, HUOVILA AP, PRIMAKOFF P et al. ADAM, a widely distributed and developmentally regulated gene family encoding membrane proteins with a disintegrin and metalloprotease domain. Dev Biol 1995; 169: 378-383. https://doi.org/10.1006/ dbio.1995.1152

[6] ZHOU M, GRAHAM R, RUSSELL G, CROUCHER PI. MDC-9 (ADAM-9/Meltrin gamma) functions as an adhesion molecule by binding the alpha(v)beta(5) integrin. Biochem Biophys Res Commun 2001; 280: 574-580. https://doi. org/10.1006/bbrc.2000.4155

[7] FRITZSCHE FR, WASSERMANN K, JUNG M, TOLLE A, KRISTIANSEN I et al. ADAM9 is highly expressed in renal cell cancer and is associated with tumor progression. BMC Cancer 2008; 8: 179. https://doi.org/10.1186/1471-2407-8-179

[8] GRUTZMANN R, LUTTGES J, SIPOS B, AMMERPOHL O, DOBROWOLSKI $\mathrm{F}$ et al. ADAM9 expression in pancreatic cancer is associated with tumor type and is a prognostic factor in ductal adenocarcinoma. Br J Cancer 2004; 90: $1053-$ 1058. https://doi.org/10.1038/sj.bjc.6601645

[9] SHINTANI Y, HIGASHIYAMA S, OHTA M, HIRABAYASHI H, YAMAMOTO $S$ et al. Overexpression of ADAM9 in Non-Small Cell Lung Cancer Correlates with Brain Metastasis. Cancer Res 2004; 64: 4190-4196. https://doi. org/10.1158/0008-5472.CAN-03-3235

[10] MAZZOCCA A, COPPARI R, DE FRANCO R, CHO J-Y, LIBERMANN TA et al. A Secreted Form of ADAM9 Promotes Carcinoma Invasion through -Stromal Interactions. Cancer Res 2005; 65: 4728-4738. https://doi. org/10.1158/0008-5472.CAN-04-4449

[11] FRITZSCHE FR, JUNG M, XU C, RABIEN A, SCHICKTANZ $\mathrm{H}$ et al. ADAM8 expression in prostate cancer is associated with parameters of unfavorable prognosis. Virchows Arch 2006; 449: 628-636. https://doi.org/10.1007/s00428006-0315-1

[12] ISHIKAWA N, DAIGO Y, YASUI W, INAI K, NISHIMURA $\mathrm{H}$ et al. ADAM8 as a Novel Serological and Histochemical Marker for Lung Cancer. Clin Cancer Res 2004; 10: 83638370. https://doi.org/10.1158/1078-0432.CCR-04-1436
[13] CAVALLO F, DE GIOVANNI C, NANNI P, FORNI G, LOLLINI PL. 2011: the immune hallmarks of cancer. Cell 2011; 60: 319-326. https://doi.org/10.1007/s00262-010-0968-0

[14] FOURIE AM, COLES F, MORENO V, KARLSSON L. Catalytic activity of ADAM8, ADAM15, and MDC-L (ADAM28) on synthetic peptide substrates and in ectodomain cleavage of CD23. J Biol Chem 2003; 278: 30469-30477. https://doi. org/10.1074/jbc.M213157200

[15] DUBEY S, VANVELDHUIZEN P, HOLZBEIERLEIN J, TAWFIK O, THRASHER JB et al. Inflammation-associated regulation of the macrophage inhibitory cytokine (MIC1) gene in prostate cancer. Oncol Lett 2012; 3: 1166-1170. https://doi.org/10.3892/ol.2012.635

[16] MATSUNO O, MIYAZAKI E, NUREKI S, UENO T, ANDO $\mathrm{M}$ et al. Elevated Soluble ADAM8 in Bronchoalveolar Lavage Fluid in Patients with Eosinophilic Pneumonia. Int Arch Allergy Immunol 2007; 142: 285-290. https://doi. org/10.1159/000097359

[17] BRIDGES LC, SHEPPARD D, BOWDITCH RD. ADAM disintegrin-like domain recognition by the lymphocyte integrins $\alpha 4 \beta 1$ and $\alpha 4 \beta 7$. Biochem J 2005; 387: 101-108. https:// doi.org/10.1042/BJ20041444

[18] NAMBA K, NISHIO M, MORI K, MIYAMOTO N, TSURUDOME $\mathrm{M}$ et al. Involvement of ADAM9 in Multinucleated Giant Cell Formation of Blood Monocytes. Cell Immunol 2001;213: 104-113. https://doi.org/10.1006/cimm.2001.1873

[19] RICHENS J, FAIRCLOUGH L, GHAEMMAGHAMI A, MAHDAVI J, SHAKIB $F$ et al. The detection of ADAM8 protein on cells of the human immune system and the demonstration of its expression on peripheral blood B cells, dendritic cells and monocyte subsets. Immunobiology 2007; 212: 29-38. https://doi.org/10.1016/j.imbio.2006.06.012

[20] DONG F, EIBACH M, BARTSCH JW, DOLGA AM, SCHLOMANN $U$ et al. The metalloprotease-disintegrin ADAM8 contributes to temozolomide chemoresistance and enhanced invasiveness of human glioblastoma cells. Neuro Oncol 2015; 17: 1474-1485. https://doi.org/10.1093/neuonc/ nov042

[21] MULLOOLY M, MCGOWAN PM, KENNEDY S A, MADDEN SF, CROWN J et al. ADAM10: a new player in breast cancer progression? Br J Cancer 2015; 113: 945-951. https:// doi.org/10.1038/bjc.2015.288

[22] RICHARDS FM, TAPE CJ, JODRELL DI, MURPHY G. Anti-tumor effects of a specific anti-ADAM17 antibody in an ovarian cancer model in vivo. PLoS One 2012; 7: 1-10. https://doi.org/10.1371/journal.pone.0040597

[23] BOLGER JC, YOUNG LS. ADAM22 as a Prognostic and Therapeutic Drug Target in the Treatment of EndocrineResistant Breast Cancer. pp 307-321. In: G. Litvak (Eds.). Hormones and Breast Cancer, vol 93, 1st Edition. Elsevier Inc.; 2013, p 386. ISBN 978-0-12-416673-8

[24] SAFTIG P, REISS K. The "A Disintegrin And Metalloproteases" ADAM10 and ADAM17: Novel drug targets with therapeutic potential? Eur J Cell Biol 2011; 90: 527-535. https:// doi.org/10.1016/j.ejcb.2010.11.005

[25] CHO C. Testicular and epididymal ADAMs: expression and function during fertilization. Nat Rev Urol 2012; 9: 550-560. https://doi.org/10.1038/nrurol.2012.167 
[26] EDWARDS DR, HANDSLEY MM, PENNINGTON CJ. The ADAM metalloproteinases. Mol Aspects Med 2009; 29: 258289. https://doi.org/10.1016/j.mam.2008.08.001

[27] BLAKE JA, CHRISTIE KR, DOLAN ME, DRABKIN HJ, HILL DP et al. Gene Ontology Consortium: going forward. Nucleic Acids Res 2015; 43: D1049-D1056. https://doi. org/10.1093/nar/gku1179

[28] MOCHIZUKI S, OKADA Y. ADAMs in cancer cell proliferation and progression. Cancer Sci 2007; 98: 621-628. https:// doi.org/10.1111/j.1349-7006.2007.00434.x

[29] MURPHY G. The ADAMs: signaling scissors in the tumor microenvironment. Nat Rev Cancer 2008; 8: 929-941. https://doi.org/10.1038/nrc2459

[30] LIU P, CHENG H, ROBERTS TM, ZHAO JJ. Targeting the phosphoinositide 3-kinase pathway in cancer. Nat Rev Drug Discov 2009; 8: 627-644. https://doi.org/10.1038/nrd2926

[31] FRESNO VARA JA, CASADO E, DE CASTRO J, CEJAS P, BELDA-INIESTA $\mathrm{C}$ et al. PI3K/Akt signaling pathway and cancer. Cancer Treat Rev 2004; 30: 193-204. https://doi. org/10.1016/j.ctrv.2003.07.007

[32] LIU S, ZHANG W, LIU K, JI B, WANG G. Silencing ADAM10 inhibits the in vitro and in vivo growth of hepatocellular carcinoma cancer cells. Mol Med Rep 2015; 11 : 597-602. https://doi.org/10.3892/mmr.2014.2652

[33] DI DOMENICO M, GIORDANO A. Signal transduction growth factors: the effective governance of transcription and cellular adhesion in cancer invasion. Oncotarget 2017; 8: 36869-36884. https://doi.org/10.18632/oncotarget.16300

[34] PULIAFITO A, HUFNAGEL L, NEVEU P, STREICHAN S, SIGAL A et al. Collective and single cell behavior in epithelial contact inhibition. Proc Natl Acad Sci U S A 2012; 109: 739-744. https://doi.org/10.1073/pnas.1007809109

[35] HOLMES WR, PARK J, LEVCHENKO A, EDELSTEINKESHET L. A mathematical model coupling polarity signaling to cell adhesion explains diverse cell migration patterns. PLoS Comput Biol 2017; 13: e1005524. https://doi. org/10.1371/journal.pcbi.1005524

[36] SU C, ZHANG B, LIU W, ZHENG H, SUN L et al. High extracellular pressure promotes gastric cancer cell adhesion, invasion, migration and suppresses gastric cancer cell differentiation. Oncol Rep 2016; 36: 1048-1054. https://doi. org/10.3892/or.2016.4841

[37] WORTMANN A, HE Y, DERYUGINA EI, QUIGLEY JP, HOOPER JD. The cell surface glycoprotein CDCP1 in cancer - Insights, opportunities, and challenges. IUBMB Life 2009; 61: 723-730. https://doi.org/10.1002/iub.198

[38] CHIU KL, KUO TT, KUOK QY, LIN YS, HUA CH et al. ADAM9 enhances CDCP1 protein expression by suppressing miR-218 for lung tumor metastasis. Sci Rep 2015; 5: 16426. https://doi.org/10.1038/srep16426

[39] MARTIN ACBM, CARDOSO ACF, SELISTRE-DE-ARAUJO HS, COMINETTI MR. Recombinant disintegrin domain of human ADAM9 inhibits migration and invasion of DU145 prostate cells. Cell Adhes Migr 2015; 9: 293-299. https://doi.org/10.4161/19336918.2014.994917

[40] CHEN JC, CHEN YJ, LIN CY, FONG YC, HSU CJ et al. Amphiregulin enhances alpha6betal integrin expression and cell motility in human chondrosarcoma cells through Ras/ Raf/MEK/ERK/AP-1 pathway. Oncotarget 2015; 6: 1143411446. https://doi.org/10.18632/oncotarget.3397
[41] DAI J, DOU K, WANG C, ZHAO P, LAU WB et al. The interaction of HAb18G/CD147 with integrin alpha6betal and its implications for the invasion potential of human hepatoma cells. BMC Cancer 2009; 9: 337. https://doi. org/10.1186/1471-2407-9-337

[42] SCHLOMANN U, KOLLER G, CONRAD C, FERDOUS T, GOLFI $P$ et al. ADAM8 as a drug target in pancreatic cancer. Nat Commun 2015; 6: 6175. https://doi.org/10.1038/ncomms7175

[43] YANG Z, BAI Y, HUO L, CHEN H, HUANG J et al. Expression of $\mathrm{A}$ disintegrin and metalloprotease 8 is associated with cell growth and poor survival in colorectal cancer. BMC Cancer 2014; 14: 568. https://doi.org/10.1186/1471-2407-14568

[44] HSU HH, KUO WW, DAY CH, SHIBU MA, LI SY et al. Taiwanin $\mathrm{E}$ inhibits cell migration in human LoVo colon cancer cells by suppressing MMP-2/9 expression via p38 MAPK pathway. Environ Toxicol 2016; 24: 296-303. https://doi. org/10.1002/tox.22379

[45] TROVATO M, SIRACUSA M, CAMPENNI A, RUGGERI R. Hepatocyte Growth Factor/C-Met Axis in Thyroid Cancer: From Diagnostic Biomarker to Therapeutic Target. Biomark Insights 2017; 12.https://doi.org/10.1177/1177271917701126

[46] CHEN X, KHAJEH JA, JU JH, GUPTA YK, STANLEY CB et al. Phosphatidylinositol 4,5-bisphosphate clusters the cell adhesion molecule CD44 and assembles a specific CD44Ezrin heterocomplex, as revealed by small angle neutron scattering. J Biol Chem 2015; 290: 6639-6652. https://doi. org/10.1074/jbc.M114.589523

[47] WESSLER S, KRISCH LM, ELMER DP, ABERGER F. From inflammation to gastric cancer - the importance of Hedgehog/GLI signaling in Helicobacter pylori-induced chronic inflammatory and neoplastic diseases. Cell Commun Signal 2017; 15: 15. https://doi.org/10.1186/s12964-017-0171-4

[48] HOVDE O, HOIVIK ML, HENRIKSEN M, SOLBERG IC, SMASTUEN MC et al. Malignancies in patients with inflammatory bowel disease: Results from 20 years of follow-up in the IBSEN study. J Crohns Colitis 2017;11: 571-577. https:// doi.org/10.1093/ecco-jcc/jjw193

[49] WANG Y, MA H, ZHAO C, LIU T, YAN D et al. Growthsuppressive activity of raloxifene on liver cancer cells by targeting IL-6/GP130 signaling. Oncotarget 2017; 8: 3368333693. https://doi.org/10.18632/oncotarget.16898

[50] LU C, TALUKDER A, SAVAGE NM, SINGH N, LIU K. JAKSTAT-mediated chronic inflammation impairs cytotoxic T lymphocyte activation to decrease anti-PD-1 immunotherapy efficacy in pancreatic cancer. Oncoimmunology 2017; 6: e1291106. https://doi.org/10.1080/2162402X.2017.1291106

[51] CHANG L, GONG F, CAI H, LI Z, CUI Y. Combined RNAi targeting human Stat3 and ADAM9 as gene therapy for non-small cell lung cancer. Oncol Lett 2016; 11: 1242-1250. https://doi.org/10.3892/ol.2015.4018

[52] CHEN J, DENG L, DREYMÜLLER D, JIANG X, LONG J et al. A novel peptide ADAM8 inhibitor attenuates bronchial hyperresponsiveness and Th2 cytokine mediated inflammation of murine asthmatic models. Sci Rep 2016; 6: 30451. https://doi.org/10.1038/srep30451 
[53] ATRETKHANY K-SN, DRUTSKAYA MS. Myeloid-derived suppressor cells and proinflammatory cytokines as targets for cancer therapy. Biochemistry (Mosc) 2016; 81: 12741283. https://doi.org/10.1134/S0006297916110055

[54] RIETHMUELLER S, EHLERS JC, LOKAU J, DUSTERHOFT S, KNITTLER K et al. Cleavage Site Localization Differentially Controls Interleukin-6 Receptor Proteolysis by ADAM10 and ADAM17. Sci Rep 2016; 6: 25550. https://doi. org/10.1038/srep25550

[55] HIBIYA S, TSUCHIYA K, HAYASHI R, FUKUSHIMA K, HORITA $\mathrm{N}$ et al. Long-term inflammation transforms intestinal epithelial cells of colonic organoids. J Crohns Colitis 2017; 11: 621-630. https://doi.org/10.1093/ecco-jcc/jjw186

[56] YE Z, HE H, WANG H, LI W, LUO L et al. Glioma-derived ADAM10 induces regulatory B cells to suppress CD8+ T cells. PLoS One 2014; 9: e105350. https://doi.org/10.1371/ journal.pone.0105350

[57] PABOIS A, DEVALLIERE J, QUILLARD T, COULON F, GERARD $\mathrm{N}$ et al. The disintegrin and metalloproteinase ADAM10 mediates a canonical Notch-dependent regulation of IL-6 through Dll4 in human endothelial cells. Biochem Pharmacol 2015; 91: 510-521. https://doi.org/10.1016/j. bcp.2014.08.007

[58] HARTMAN ZC, POAGE GM, DEN HOLLANDER P, TSIMELZON A, HILL $J$ et al. Growth of triple-negative breast cancer cells relies upon coordinate autocrine expression of the proinflammatory cytokines IL- 6 and IL-8. Cancer Res 2013; 73: 3470-3480. https://doi.org/10.1158/0008-5472. CAN-12-4524-T

[59] KOURIE HR, KLASTERSKY J. Physical long-term sideeffects in young adult cancer survivors: germ cell tumors model. Curr Opin Oncol 2017; 29: 229-234. https://doi. org/10.1097/CCO.0000000000000375

[60] RASHID N, KOH HA, BACA HC, LIN KJ, MALECHA SE et al. Economic burden related to chemotherapy-related adverse events in patients with metastatic breast cancer in an integrated health care system. Breast Cancer (Dove Med Press) 2016; 8: 173-181. https://doi.org/10.2147/BCTT.S105618

[61] FITZNER K, OTENG-MENSAH F, DONLEY P, HECKINGER EAF. Safety of Cancer Therapies: At What Cost? Popul Health Manag 2017; 20: 318-328. https://doi.org/10.1089/ pop. 2016.0097

[62] BARNES TA, AMIR E, TEMPLETON AJ, GOMEZ-GARCIA S, NAVARRO B et al. Efficacy, safety, tolerability and price of newly approved drugs in solid tumors. Cancer Treat Rev 2017; 56: 1-7. https://doi.org/10.1016/j.ctrv.2017.03.011

[63] DAI Z, PAPP AC, WANG D, HAMPEL H, SADEE W. Genotyping panel for assessing response to cancer chemotherapy. BMC Med Genomics 2008; 1: 24. https://doi. org/10.1186/1755-8794-1-24

[64] ABDULLAH LN, CHOW EK. Mechanisms of chemoresistance in cancer stem cells. Clin Transl Med 2013;2: 3. https:// doi.org/10.1186/2001-1326-2-3

[65] GUERRA F, ARBINI AA, MORO L. Mitochondria and cancer chemoresistance. Biochim Biophys Acta 2017; 1858: 686-699. https://doi.org/10.1016/j.bbabio.2017.01.012

[66] WEIS SM, CHERESH DA. Tumor angiogenesis: Molecular pathways and therapeutic targets. Nat Med 2011; 17: 13591370. https://doi.org/10.1038/nm.2537
[67] KURZYK A. [Angiogenesis - possibilities, problems and perspectives]. Postepy Biochem 2015; 61: 25-34

[68] FERREIRA A, LAMY M, MARGARIDA ROCHA M, SILVA G, BANDEIRAS TM et al. Production and characterization of a novel Delta-like 1 functional unit as a tool for Notch pathway activation and generation of a specific antibody. Protein Expr Purif 2018; 146: 8-16. https://doi.org/10.1016/j. pep.2018.01.008

[69] DYCZYNSKA E, SUN D, YI H, SEHARA-FUJISAWA A, BLOBEL CP et al. Proteolytic processing of delta-like 1 by ADAM proteases. J Biol Chem 2007; 282: 436-444. https:// doi.org/10.1074/jbc.M605451200

[70] WEBER S, SAFTIG P. Ectodomain shedding and ADAMs in development. Development 2012; 139: 3693-3709. https:// doi.org/10.1242/dev.076398

[71] FOLKMAN J. Antiangiogenesis in cancer therapy - Endostatin and its mechanisms of action. Exp Cell Res 2006; 312: 594-607. https://doi.org/10.1016/j.yexcr.2005.11.015

[72] ABD EL-REHIM DM, OSMAN NA. Expression of a disintegrin and metalloprotease 8 and endostatin in human osteosarcoma: Implication in tumor progression and prognosis. J Egypt Natl Canc Inst 2015; 27: 1-9. https://doi.org/10.1016/j. jnci.2014.11.001

[73] FROHLICH C, KLITGAARD M, NOER JB, KOTZSCH A, NEHAMMER $C$ et al. ADAM12 is expressed in the tumor vasculature and mediates ectodomain shedding of several membrane-anchored endothelial proteins. Biochem J 2013; 452: 97-109. https://doi.org/10.1042/BJ20121558

[74] STASIKOWSKA-KANICKA O, WAGROWSKA-DANILEWICZ M, DANILEWICZ M. Immunohistochemical study on ADAM33 in sinonasal inverted papillomas and squamous cell carcinomas of the larynx. Arch Med Sci 2016; 12: 89-94. https://doi.org/10.5114/aoms.2016.57583

[75] CAOLO V, SWENNEN G, CHALARIS A, WAGENAAR A, VERBRUGGEN $S$ et al. ADAM10 and ADAM17 have opposite roles during sprouting angiogenesis. Angiogenesis 2015; 18: 13-22. https://doi.org/10.1007/s10456-014-9443-4

[76] PAN DH, WEN DY, LUO YH, CHEN G, YANG H et al. The diagnostic and prognostic values of Ki-67/MIB-1 expression in thyroid cancer: a meta-analysis with 6,051 cases. Onco Targets Ther 2017; 10: 3261-3276. https://doi.org/10.2147/ OTT.S135593

[77] MANDO P, RIZZO M, DE LA PUENTE CP, MAINO M, PONCE C et al. High Histologic Grade and High Ki-67 Expression Predict Phenotypic Alterations in Node Metastasis in Primary Breast Cancers. J Breast Cancer 2017; 20: 170. https://doi.org/10.4048/jbc.2017.20.2.170

[78] MIN K-W, KIM D-H, DO S-I, PYO J-S, CHAE SW et al. High Ki67/BCL2 index is associated with worse outcome in early stage breast cancer. Postgrad Med J 2016; 92: 707-714. https://doi.org/10.1136/postgradmedj-2015-133531

[79] ABUBAKAR M, ORR N, DALEY F, COULSON P, ALI HR et al. Prognostic value of automated KI67 scoring in breast cancer: a centralised evaluation of 8088 patients from 10 study groups. Breast Cancer Res 2016; 18: 104. https://doi. org/10.1186/s13058-016-0765-6 
[80] ZEPEDA-NUNO JS, GUERRERO-VELAZQUEZ C, DEL TORO-ARREOLA S, VEGA-MAGANA N, ANGELESSANCHEZ J et al. Expression of ADAM10, Fas, FasL and Soluble FasL in Patients with Oral Squamous Cell Carcinoma (OSCC) and their Association with Clinical-Pathological Parameters. Pathol Oncol Res 2017; 23: 345-353. https://doi. org/10.1007/s12253-016-0102-5

[81] YOU B, SHAN Y, SHI S, LI X, YOU Y. Effects of ADAM10 upregulation on progression, migration, and prognosis of nasopharyngeal carcinoma. Cancer Sci 2015; 106: 15061514. https://doi.org/10.1111/cas. 12800

[82] FU L, LIU N, HAN Y, XIE C, LI Q et al. ADAM10 regulates proliferation, invasion, and chemoresistance of bladder cancer cells. Tumor Biol 2014; 35: 9263-9268. https://doi. org/10.1007/s13277-014-2201-9

[83] QU M, QIU B, XIONG W, CHEN D, WU A. Expression of a-disintegrin and metalloproteinase 10 correlates with grade of malignancy in human glioma. Oncol Lett 2015; 9: 21572162. https://doi.org/10.3892/ol.2015.2993

[84] FAN X, WANG YY, ZHANG C, LIU L, YANG S et al. ADAM9 expression is associate with glioma tumor grade and histological type, and acts as a prognostic factor in lower-grade gliomas. Int J Mol Sci 2016; 17. https://doi.org/10.3390/ ijms 17091276

[85] PAN Y, HAN C, WANG C, HU G, LUO C et al. ADAM10 promotes pituitary adenoma cell migration by regulating cleavage of CD44 and L1. J Mol Endocrinol 2012; 49: 21-33. https://doi.org/10.1530/JME-11-0174

[86] WANG J, VOELLGER B, BENZEL J, SCHLOMANN U, NIMSKY C et al. Metalloproteinases ADAM12 and MMP14 are associated with cavernous sinus invasion in pituitary adenomas. Int J Cancer 2016; 139: 1327-1339. https:/doi. org/10.1002/ijc.30173

[87] XIONG Y, KOTIAN S, ZEIGER MA, ZHANG L, KEBEBEW E. MiR-126-3p inhibits thyroid cancer cell growth and metastasis, and is associated with aggressive thyroid cancer. PLoS One 2015; 10: e0130496. https://doi.org/10.1371/journal.pone. 0130496

[88] TAKEBE N, NGUYEN D, YANG SX. Targeting notch signaling pathway in cancer: clinical development advances and challenges. Pharmacol Ther 2014; 141: 140-149. https://doi. org/10.1016/j.pharmthera.2013.09.005

[89] CHEON D-J, LI AJ, BEACH J A., WALTS AE, TRAN H et al. ADAM12 is a prognostic factor associated with an aggressive molecular subtype of high-grade serous ovarian carcinoma. Carcinogenesis 2015; 36: 739-747. https://doi.org/10.1093/ carcin/bgv059

[90] LEE HD, KIM YH, KOO BH, KIM DS. The ADAM15 ectodomain is shed from secretory exosomes. BMB Rep 2015; 48: 277-282. https://doi.org/10.5483/BMBRep.2015.48.5.161

[91] SINNATHAMBY G, ZERFASS J, HAFNER J, BLOCK P, NICKENS $Z$ et al. ADAM metallopeptidase domain 17 (ADAM17) is naturally processed through major histocompatibility complex (MHC) class I molecules and is a potential immunotherapeutic target in breast, ovarian and prostate cancers. Clin Exp Immunol 2011; 163: 324-332. https://doi. org/10.1111/j.1365-2249.2010.04298.x
[92] CHAN MW, HUANG Y-W, HARTMAN-FREY C, KUO C-T, DEATHERAGE D et al. Aberrant transforming growth factor beta1 signaling and SMAD4 nuclear translocation confer epigenetic repression of ADAM19 in ovarian cancer. Neoplasia 2008; 10: 908-919. https://doi.org/10.1593/neo.08540

[93] PUOLAKKAINEN P, KOSKI A, VAINIONPAA S, SHEN $\mathrm{Z}$, REPO $\mathrm{H}$ et al. Anti-inflammatory macrophages activate invasion in pancreatic adenocarcinoma by increasing the MMP9 and ADAM8 expression. Med Oncol 2014; 31. https://doi.org/10.1007/s12032-014-0884-9

[94] ROMAGNOLI M, MINEVA ND, POLMEAR M, CONRAD C, SRINIVASAN $S$ et al. ADAM8 expression in invasive breast cancer promotes tumor dissemination and metastasis. EMBO Mol Med 2014; 6: 278-294. https://doi.org/10.1002/ emmm.201303373

[95] ZIELINSKI V, BRUNNER M, HEIDUSCHKA G, SCHNEIDER S, SEEMANN R et al. ADAM8 in squamous cell carcinoma of the head and neck: a retrospective study. BMC Cancer 2012; 12: 76. https://doi.org/10.1186/1471-2407-1276

[96] CHEN CM, HSIEH YH, HWANG JM, JAN HJ, HSIEH SC et al. Fisetin suppresses ADAM9 expression and inhibits invasion of glioma cancer cells through increased phosphorylation of ERK1/2. Tumor Biol 2015; 36: 3407-3415. https://doi. org/10.1007/s13277-014-2975-9

[97] LIU X, WANG S, YUAN A, YUAN X, LIU B. MicroRNA-140 represses glioma growth and metastasis by directly targeting ADAM9. Oncol Rep 2016; 36: 2329-2338. https://doi. org/10.3892/or.2016.5007

[98] MICOCCI KC, MORITZ MN DE O, LINO RLB, FERNANDES LR, LIMA AGF et al. ADAM9 silencing inhibits breast tumor cells transmigration through blood and lymphatic endothelial cells. Biochimie. 2016; 128-129: 174-182. doi:10.1016/j.biochi.2016.08.006

[99] ZHANG C, ZHANG Y, DING W, LIN Y, HUANG Z et al. MiR-33a suppresses breast cancer cell proliferation and metastasis by targeting ADAM9 and ROS1. Protein Cell 2015; 6: 881-889. https://doi.org/10.1007/s13238-015-0223-8

[100] LIU CM, HSIEH CL, HE YC, LO SJ, LIANG JA et al. In Vivo Targeting of ADAM9 Gene Expression Using Lentivirus-Delivered shRNA Suppresses Prostate Cancer Growth by Regulating REG4 Dependent Cell Cycle Progression. PLoS One 2013; 8: 1-12. https://doi.org/10.1371/journal.pone.0053795

[101] LI J, JI Z, QIAO C, QI Y, SHI W. Overexpression of ADAM9 promotes colon cancer cells invasion. J Investig Surg 2013; 26: 127-133. https://doi.org/10.3109/08941939.2012.728682

[102] HAMADA S, SATOH K, FUJIBUCHI W, HIROTA M, KANNO A et al. MiR-126 acts as a tumor suppressor in pancreatic cancer cells via the regulation of ADAM9. Mol Cancer Res 2012; 10: 3-10. https://doi.org/10.1158/1541-7786.MCR-110272

[103] ZOCCHI MR, CAMODECA C, NUTI E, ROSSELLO A, VENE R et al. ADAM10 new selective inhibitors reduce NKG2D ligand release sensitizing Hodgkin lymphoma cells to NKG2D-mediated killing. Oncoimmunology 2016; 5: e1123367. https://doi.org/10.1080/2162402X.2015.1123367 
[104] EBBING EA, MEDEMA JP, DAMHOFER H, MEIJER SL, KRISHNADATH KK et al. ADAM10-mediated release of heregulin confers resistance to trastuzumab by activating HER3. Oncotarget 2016; 7: 10243-10254. https://doi. org/10.18632/oncotarget.7200

[105] ATAPATTU L, SAHA N, CHHEANG C, EISSMAN MF, XU $\mathrm{K}$ et al. An activated form of ADAM10 is selective and regulates cancer stem-like cells and tumor growth. J Exp Med 2016; 213: 1741-1757. https://doi.org/10.1084/jem.20151095

[106] CALTABIANO R, PUZZO L, BARRESI V, IENI A, LORETO $\mathrm{C}$ et al. ADAM 10 expression in primary uveal melanoma as prognostic factor for risk of metastasis. Pathol Res Pract 2016; 212: 980-987. https://doi.org/10.1016/j.prp.2016.08.003

[107] WOODS N, TREVINO J, COPPOLA D, CHELLAPPAN S, YANG $S$ et al. Fendiline inhibits proliferation and invasion of pancreatic cancer cells by interfering with ADAM10 activation and $\beta$-catenin signaling. Oncotarget 2015; 6: 3593135948. https://doi.org/10.18632/oncotarget.5933

[108] WOJTALEWICZ N, SADEQZADEH E, WEIß J V., TEHRANI MM, KLEIN-SCORY S et al. A soluble form of the giant cadherin Fat1 is released from pancreatic cancer cells by ADAM10 mediated ectodomain shedding. PLoS One 2014; 9: e90461. https://doi.org/10.1371/journal.pone.0090461

[109] ERGUN S, ULASLI M, IGCI YZ, IGCI M, KIRKBES S et al. The association of the expression of miR-122-5p and its target ADAM10 with human breast cancer. Mol Biol Rep 2015; 42: 497-505. https://doi.org/10.1007/s11033-014-3793-2

[110] FELDINGER K, GENERALI D, KRAMER-MAREK G, GIJSEN M, NG TB et al. ADAM10 mediates trastuzumab resistance and is correlated with survival in HER2 positive breast cancer. Oncotarget 2014; 5: 6633-6646. https://doi. org/10.18632/oncotarget.1955

[111] MUSUMECI G, MAGRO G, CARDILE V, COCO M, MARZAGALLI $\mathrm{R}$ et al. Characterization of matrix metalloproteinase-2 and -9, ADAM-10 and N-cadherin expression in human glioblastoma multiforme. Cell Tissue Res 2015; 362: 45-60. https://doi.org/10.1007/s00441-015-2197-5

[112] WOLPERT F, TRITSCHLER I, STEINLE A, WELLER M, EISELE G. A disintegrin and metalloproteinases 10 and 17 modulate the immunogenicity of glioblastoma-initiating cells. Neuro Oncol 2014; 16: 382-391. https://doi. org/10.1093/neuonc/not232

[113] ZHANG W, LIU S, LIU K, WANG Y, JI B et al. A disintegrin and metalloprotease (ADAM) 10 is highly expressed in hepatocellular carcinoma and is associated with tumor progression. J Int Med Res 2014; 42: 611-618. https://doi. org/10.1177/0300060513505500

[114] ZHANG W, LIU S, LIU K, JI B, WANG Y et al. Knockout of ADAM10 enhances sorafenib anti activity of hepatocellular carcinoma in vitro and in vivo. Oncol Rep 2014; 32: 19131922. https://doi.org/10.3892/or.2014.3418

[115] KAI Y, PENG W, LING W, JIEBING H, ZHUAN B. Reciprocal effects between microRNA-140-5p and ADAM10 suppress migration and invasion of human tongue cancer cells. Biochem Biophys Res Commun 2014; 448: 308-314. https:// doi.org/10.1016/j.bbrc.2014.02.032
[116] JONES A V, LAMBERT DW, SPEIGHT PM, WHAWELL SA. ADAM 10 is over expressed in oral squamous cell carcinoma and contributes to invasive behaviour through a functional association with $\alpha v \beta 6$ integrin. FEBS Lett 2013; 587: 3529-3534. https://doi.org/10.1016/j.febslet.2013.09.010

[117] GUO J, HE L, YUAN P, WANG P, LU Y et al. ADAM10 overexpression in human non-small cell lung cancer correlates with cell migration and invasion through the activation of the Notch1 signaling pathway. Oncol Rep 2012; 28: 17091718. https://doi.org/10.3892/or.2012.2003

[118] RAO VH, VOGEL K, YANAGIDA JK, MARWAHA N, KANDEL A et al. Erbb2 up-regulation of ADAM12 expression accelerates skin cancer progression. Mol Carcinog 2015; 54: 1026-1036. https://doi.org/10.1002/mc.22171

[119] SHAO S, LI Z, GAO W, YU G, LIU D et al. ADAM-12 as a diagnostic marker for the proliferation, migration and invasion in patients with small cell lung cancer. PLoS One 2014; 9: e85936. https://doi.org/10.1371/journal.pone.0085936

[120] GEORGES S, CHESNEAU J, HERVOUET S, TAURELLE J, GOUIN F et al. A Disintegrin and Metalloproteinase 12 produced by tumor cells accelerates osteosarcoma tumor progression and associated osteolysis. Eur J Cancer 2013; 49: 2253-2263. https://doi.org/10.1016/j.ejca.2013.02.020

[121] CIREAP N, NARITA D. Molecular profiling of ADAM12 and ADAM17 genes in human malignant melanoma. Pathol Oncol Res 2013; 19: 755-762. https://doi.org/10.1007/ s12253-013-9639-8

[122] SHIMURA T, DAGHER A, SACHDEV M, EBI M, YAMADA $\mathrm{T}$ et al. Urinary ADAM12 and MMP-9/NGAL complex detect the presence of gastric cancer. Cancer Prev Res 2015; 8: 240-248. https://doi.org/10.1158/1940-6207.CAPR-14-0229

[123] DONG DD, ZHOU H, LI G. ADAM15 targets MMP9 activity to promote lung cancer cell invasion. Oncol Rep 2015; 34: 2451-2460. https://doi.org/10.3892/or.2015.4203

[124] NA HW, SHIN WS, LUDWIG A, LEE ST. The cytosolic domain of protein-tyrosine kinase 7 (PTK7), generated from sequential cleavage by a disintegrin and metalloprotease 17 (ADAM17) and $\gamma$-secretase, enhances cell proliferation and migration in colon cancer cells. J Biol Chem 2012; 287: 25001-25009. https://doi.org/10.1074/jbc.M112.348904

[125] ZHANG T, ZHU W, HUANG M, FAN R, CHEN X. Prognostic value of ADAM17 in human gastric cancer. Med Oncol 2012; 29: 2684-2690. https://doi.org/10.1007/s12032-0110125-4

[126] XIAO LJ, LIN P, LIN F, LIU X, QIN W et al. ADAM17 targets MMP-2 and MMP-9 via EGFR-MEK-ERK pathway activation to promote prostate cancer cell invasion. Int J Oncol 2012; 40: 1714-1724. https://doi.org/10.3892/ijo.2011.1320

[127] MCCARTAN D, BOLGER JC, FAGAN A, BYRNE C, HAO $\mathrm{Y}$ et al. Global characterization of the SRC-1 transcriptome identifies ADAM22 as an ER-independent mediator of endocrine-resistant breast cancer. Cancer Res 2012; 72: 220-229. https://doi.org/10.1158/0008-5472.CAN-11-1976

[128] ZHANG XH, WANG CC, JIANG Q, YANG SM, JIANG H et al. ADAM28 overexpression regulated via the PI3K/Akt pathway is associated with relapse in de novo adult B-cell acute lymphoblastic leukemia. Leuk Res 2015; 39: 12291238. https://doi.org/10.1016/j.leukres.2015.08.006 
[129] TWITO T, CHEN Z, KHATRI I, WONG K, SPANER D et al. Ectodomain shedding of CD200 from the B-CLL cell surface is regulated by ADAM28 expression. Leuk Res 2013; 37: 816-821. https://doi.org/10.1016/j.leukres.2013.04.014

[130] MOCHIZUKI S, SOEJIMA K, SHIMODA M, ABE H, SASAKI A et al. Effect of ADAM28 on carcinoma cell metastasis by cleavage of von willebrand factor. J Natl Cancer Inst 2012; 104: 906-922. https://doi.org/10.1093/jnci/djs232

[131] LV YL, YUAN DM, WANG QB, ZHAN P, LUO L et al. Baseline and decline of serum ADAM28 during chemotherapy of advanced non-small cell lung cancer: A probable predictive and prognostic factor. Med Oncol 2012; 29: 2633-2639. https://doi.org/10.1007/s12032-012-0180-5

[132] ZHAO M, JIA W, JIANG WG, WANG P, DU G et al. ADAM29 Expression in Human Breast Cancer and its Effects on Breast Cancer Cells In Vitro. Anticancer Res 2016; 36: $1251-1258$

[133] KUHN PH, COLOMBO AV, SCHUSSER B, DREYMUELLER D, WETZEL $S$ et al. Systematic substrate identification indicates a central role for the metalloprotease ADAM10 in axon targeting and synapse function. Elife 2016; 5: e12748. https://doi.org/10.7554/eLife.12748.001

[134] BARTSCH JW, WILDEBOER D, KOLLER G, NAUS S, RITTGER A et al. Tumor Necrosis Factor- $\alpha$ (TNF- $\alpha$ ) regulates shedding of TNF- $\alpha$ receptor 1 by the metalloprotease-disintegrin ADAM8: evidence for a proteaseregulated feedback loop in neuroprotection. J Neurosci 2010; 30: 12210-12218. https://doi.org/10.1523/JNEUROSCI.1520-10.2010

[135] GUAIQUIL VH, SWENDEMAN S, ZHOU W, GUAIQUIL $\mathrm{P}$, WESKAMP G et al. ADAM8 is a negative regulator of retinal neovascularization and of the growth of heterotopically injected tumor cells in mice. J Mol Med 2010; 88: 497-505. https://doi.org/10.1007/s00109-010-0591-8

[136] ZACKMD,MALFAITAM,SKEPNERAP,YATESMP,GRIGGS DW et al. ADAM-8 isolated from human osteoarthritic chondrocytes cleaves fibronectin at Ala271. Arthritis Rheum 2009; 60: 2704-2713. https://doi.org/10.1002/art.24753

[137] ROYCHAUDHURI R, HERGRUETER AH, POLVERINO F, LAUCHO-CONTRERAS ME, GUPTA K et al. ADAM9 Is a NovelProduct of PolymorphonuclearNeutrophils:Regulation of Expression and Contributions to Extracellular Matrix Protein Degradation during Acute Lung Injury. J Immunol 2014; 193: 2469-2482. https://doi.org/10.4049/jimmunol.1303370

[138] GUAIQUIL V, SWENDEMAN S, YOSHIDA T, CHAVALA S, CAMPOCHIARO P A et al. ADAM9 is involved in pathological retinal neovascularization. Mol Cell Biol 2009; 29: 2694-2703. https://doi.org/10.1128/MCB.01460-08

[139] BENDER M, HOFMANN S, STEGNER D, CHALARIS A, BOSL $\mathrm{M}$ et al. Differentially regulated GPVI ectodomain shedding by multiple platelet-expressed proteinases. Blood 2010; 116: 3347-3355. https://doi.org/10.1182/ blood-2010-06-289108

[140] AGHABABAEI M, HOGG K, PERDU S, ROBINSON WP, BERISTAIN AG. ADAM12-directed ectodomain shedding of E-cadherin potentiates trophoblast fusion. Cell Death Differ 2015; 22: 1970-1984. https://doi.org/10.1038/cdd.2015.44
[141] LORENZATTI HILES GL, BUCHEIT A, RUBIN JR, HAYWARD A, CATES AL et al. ADAM15 is functionally associated with the metastatic progression of human bladder cancer. PLoS One 2016; 11: e0150138. https://doi.org/10.1371/ journal.pone.0150138

[142] MARETZKY T, YANG G, OUERFELLI O, OVERALL CM, WORPENBERG $S$ et al. Characterization of the catalytic activity of the membrane-anchored metalloproteinase ADAM15 in cell-based assays. Biochem J 2009; 420: 105113. https://doi.org/10.1042/BJ20082127

[143] NAJY AJ, DAY KC, DAY ML. ADAM15 supports prostate cancer metastasis by modulating tumor cell-endothelial cell interaction. Cancer Res 2008; 68: 1092-1099. https://doi. org/10.1158/0008-5472.CAN-07-2432

[144] MENGHINI R, FIORENTINO L, CASAGRANDE V, LAURO R, FEDERICI M. The role of ADAM17 in metabolic inflammation. Atherosclerosis 2013; 228: 12-17. https://doi. org/10.1016/j.atherosclerosis.2013.01.024

[145] YOSHIKAWA A, AIZAKI Y, KUSANO KI, KISHI F, SUSUMU $\mathrm{T}$ et al. The (pro)renin receptor is cleaved by ADAM19 in the Golgi leading to its secretion into extracellular space. Hypertens Res 2011; 34: 599-605. https://doi. org/10.1038/hr.2010.284

[146] YANG CY, CHANALARIS A, TROEBERG L. ADAMTS and ADAM metalloproteinases in osteoarthritis - looking beyond the "usual suspects.Osteoarthritis Cartilage 2017; 25: 1000-1009. https://doi.org/10.1016/j.joca.2017.02.791

[147] MIYAMAE Y, MOCHIZUKI S, SHIMODA M, OHARA $\mathrm{K}, \mathrm{ABE} \mathrm{H}$ et al. ADAM28 is expressed by epithelial cells in human normal tissues and protects from C1q-induced cell death. FEBS J 2016; 283: 1574-1594. https://doi.org/10.1111/ febs. 13693

[148] LETRONNE F, LAUMET G, AYRAL AM, CHAPUIS J, DEMIAUTTE F et al. ADAM30 Downregulates APP-Linked Defects Through Cathepsin D Activation in Alzheimer's Disease. EBioMedicine 2016; 9: 278-292. https://doi. org/10.1016/j.ebiom.2016.06.002

[149] REISS K, SAFTIG P. The „a disintegrin and metalloprotease" (ADAM) family of sheddases: physiological and cellular functions. Semin Cell Dev Biol 2009; 20: 126-137. https:// doi.org/10.1016/j.semcdb.2008.11.002

[150] NISHIMURA H, KIM E, NAKANISHI T, BABA T. Possible function of the ADAM1a/ADAM2 fertilin complex in the appearance of ADAM3 on the sperm surface. J Biol Chem 2004; 279: 34957-34962. https://doi.org/10.1074/jbc. M314249200

[151] HAN C, KWON JT, PARK I, LEE B, JIN S et al. Impaired sperm aggregation in Adam2 and Adam3 null mice. Fertil Steril 2010; 93: 2754-2756. https://doi.org/10.1016/j.fertnstert.2010.03.013

[152] STEIN KK, GO JC, PRIMAKOFF P, MYLES DG. Defects in Secretory Pathway Trafficking During Sperm Development in Adam2 Knockout Mice. Biol Reprod 2005; 73: 1032-1038. https://doi.org/10.1095/biolreprod.105.040972

[153] YAMAGUCHI R, MURO Y, ISOTANI A, TOKUHIRO K, TAKUMI K et al. Disruption of ADAM3 Impairs the Migration of Sperm into Oviduct in Mouse1. Biol Reprod 2009; 81: 142-146. https://doi.org/10.1095/biolreprod.108.074021 
[154] TOKUHIRO K, IKAWA M, BENHAM AM, OKABE M. Protein disulfide isomerase homolog PDILT is required for quality control of sperm membrane protein ADAM3 and male fertility. Proc Natl Acad Sc U S A 2012; 109: 3850-3855. https://doi.org/10.1073/pnas.1117963109

[155] KELLY K, HUTCHINSON G, NEBENIUS-OOSTHUIZEN D, SMITH AJ, BARTSCH JW et al. Metalloprotease-disintegrin ADAM8: Expression analysis and targeted deletion in mice. Dev Dyn 2005; 232: 221-231. https://doi.org/10.1002/ dvdy.20221

[156] ISHIZUKA H, GARCIA-PALACIOS V, LU G, SUBLER MA, ZHANG $\mathrm{H}$ et al. ADAM8 enhances osteoclast precursor fusion and osteoclast formation in vitro and in vivo. J Bone Miner Res 2011; 26: 169-181. https://doi.org/10.1002/ jbmr.199

[157] NAUS S, BLANCHET MR, GOSSENS K, ZAPH C, BARTSCH JW et al. The metalloprotease-disintegrin ADAM8 is essential for the development of experimental asthma. Am J Respir Crit Care Med 2010; 181: 1318-1328. https://doi.org/10.1164/rccm.200909-1396OC

[158] ZACK MD, MELTON MA, STOCK JL, STORER CE, BARVE RA et al. Reduced incidence and severity of experimental autoimmune arthritis in mice expressing catalytically inactive A disintegrin and metalloproteinase 8 (ADAM8). Clin Exp Immunol 2009; 158: 246-256. https://doi.org/10.1111/ j.1365-2249.2009.04009.x

[159] WESKAMP G, CAI H, BRODIE T A, HIGASHYAMA S, MANOVA $\mathrm{K}$ et al. Mice lacking the metalloprotease-disintegrin MDC9 (ADAM9) have no evident major abnormalities during development or adult life. Mol Cell Biol 2002; 22: 1537-1544. https://doi.org/10.1128/MCB.22.5.15371544.2002

[160] PARRY DA, TOOMES C, BIDA L, DANCIGER M, TOWNS $\mathrm{KV}$ et al. Loss of the Metalloprotease ADAM9 Leads to Cone-Rod Dystrophy in Humans and Retinal Degeneration in Mice. Am J Hum Genet 2009; 84: 683-691. https://doi. org/10.1016/j.ajhg.2009.04.005

[161] MAUCH C, ZAMEK J, ABETY AN, GRIMBERG G, FOX JW et al. Accelerated wound repair in ADAM-9 knockout animals. J Invest Dermatol 2010; 130: 2120-2130. https://doi. org/10.1038/jid.2010.60

[162] AIKEN A, KHOKHA R. Unraveling metalloproteinase function in skeletal biology and disease using genetically altered mice. Biochim Biophys Acta - Mol Cell Res 2010; 1803: 121132. https://doi.org/10.1016/j.bbamcr.2009.07.002

[163] ALABI RO, GLOMSKI K, HAXAIRE C, WESKAMP G, MONETTE S et al. ADAM10-Dependent Signaling Through Notch 1 and Notch4 Controls Development of Organ-Specific Vascular Beds. Circ Res 2016; 119: 519-531. https://doi. org/10.1161/CIRCRESAHA.115.307738

[164] GLOMSKI K, MONETTE S, MANOVA K, DE STROOPER B, SAFTIG P et al. Deletion of Adam10 in endothelial cells leads to defects in organ-specific vascular structures. Blood 2011; 118: 1163-1174. https://doi.org/10.1182/ blood-2011-04-348557
[165] PROX J, BERNREUTHER C, ALTMEPPEN H, GRENDEL J, GLATZEL $M$ et al. Postnatal disruption of the disintegrin/ metalloproteinase ADAM10 in brain causes epileptic seizures, learning deficits, altered spine morphology, and defective synaptic functions. J Neurosci 2013; 33: 12915-12928. https://doi.org/10.1523/JNEUROSCI.5910-12.2013

[166] JORISSEN E, PROX J, BERNREUTHER C, WEBER S, SCHWANBECK R et al. The Disintegrin/Metalloproteinase ADAM10 Is Essential for the Establishment of the Brain Cortex. J Neurosci 2010; 30: 4833-4844. https://doi.org/10.1523/ JNEUROSCI.5221-09.2010

[167] WEBER S, NIESSEN MT, PROX J, LULLMANN-RAUCH $\mathrm{R}$, SCHMITZ A et al. The disintegrin/metalloproteinase Adam10 is essential for epidermal integrity and Notch-mediated signaling. Development 2011; 138: 495-505. https:// doi.org/10.1242/dev.055210

[168] INOSHIMA N, WANG Y, BUBECK WARDENBURG J. Genetic requirement for ADAM10 in severe Staphylococcus aureus skin infection. J Invest Dermatol 2012; 132: 1513 1516. https://doi.org/10.1038/jid.2011.462

[169] CHAIMOWITZ NS, MARTIN RK, CICHY J, GIBB DR, PATIL $P$ et al. A Disintegrin and Metalloproteinase 10 Regulates Antibody Production and Maintenance of Lymphoid Architecture. J Immunol 2011; 187: 5114-5122. https://doi. org/10.4049/jimmunol.1102172

[170] GIBB DR, SALEEM SJ, KANG D-J, SUBLER MA, CONRAD DH. ADAM10 Overexpression Shifts Lympho- and Myelopoiesis by Dysregulating Site 2/Site 3 Cleavage Products of Notch. J Immunol 2011; 186: 4244-4252. https://doi. org/10.4049/jimmunol.1003318

[171] TAKAHASHI E, SAGANE K, NAGASU T, KUROMITSU J. Altered nociceptive response in ADAM11-deficient mice. Brain Res 2006; 1097: 39-42. https://doi.org/10.1016/j. brainres.2006.04.043

[172] TAKAHASHI E, SAGANE K, OKI T, YAMAZAKI K, NAGASU T et al. Deficits in spatial learning and motor coordination in ADAM11-deficient mice. BMC Neurosci 2006; 7: 19. https://doi.org/10.1186/1471-2202-7-19

[173] KURISAKI T, MASUDA A, SUDO K, SAKAGAMI J, HIGASHIYAMA S et al. Phenotypic analysis of Meltrin alpha (ADAM12)-deficient mice: involvement of Meltrin alpha in adipogenesis and myogenesis. Mol Cell Biol 2003; 23: $55-61$

[174] FROHLICH C, NEHAMMER C, ALBRECHTSEN R, KRONQVIST P, KVEIBORG $M$ et al. ADAM12 Produced by tumor cells rather than stromal cells accelerates breast tumor progression. Mol Cancer Res 2011; 9: 1449-1461. https://doi. org/10.1158/1541-7786.MCR-11-0100

[175] HARSHA A, STOJADINOVIC O, BREM H, SEHARA-FUJISAWA A, WEWER U et al. ADAM12: A potential target for the treatment of chronic wounds. J Mol Med 2008; 86: 961-969. https://doi.org/10.1007/s00109-008-0353-z

[176] MASAKI M, KURISAKI T, SHIRAKAWA K, SEHARAFUJISAWA A. Role of meltrin a (ADAM12) in obesity induced by high-fat diet. Endocrinology 2005; 146: 1752-1763. https://doi.org/10.1210/en.2004-1082 
[177] SUN C, BEARD RS, MCLEAN DL, RIGOR RR, KONIA T et al. ADAM15 deficiency attenuates pulmonary hyperpermeability and acute lung injury in lipopolysaccharide-treated mice. AJP Lung Cell Mol Physiol 2013; 304: L135-L142. https://doi.org/10.1152/ajplung.00133.2012

[178] BÖHM BB, AIGNER T, ROY B, BRODIE TA, BLOBEL CP et al. Homeostatic effects of the metalloproteinase disintegrin ADAM15 in degenerative cartilage remodeling. Arthritis Rheum2005;52:1100-1109.https://doi.org/10.1002/art.20974

[179] JACKSON LF, QIU TH, SUNNARBORG SW, CHANG A, ZHANG $\mathrm{C}$ et al. Defective valvulogenesis in HB-EGF and TACE-null mice is associated with aberrant BMP signaling. EMBO J 2003; 22: 2704-2716. https://doi.org/10.1093/emboj/cdg264

[180] SHI W, CHEN H, SUN J, BUCKLEY S, ZHAO J et al. TACE is required for fetal murine cardiac development and modeling. Dev Biol 2003; 261: 371-380. https://doi.org/10.1016/ S0012-1606(03)00315-4

[181] CHALARIS A, ADAM N, SINA C, ROSENSTIEL P, LEHMANN-KOCH J et al. Critical role of the disintegrin metalloprotease ADAM17 for intestinal inflammation and regeneration in mice. J Exp Med 2010; 207: 1617-1624. https://doi. org/10.1084/jem.20092366

[182] WESKAMP G, MENDELSON K, SWENDEMAN S, LE GALL S, MA Y et al. Pathological neovascularization is reduced by inactivation of ADAM17 in endothelial cells but not in pericytes. Circ Res 2010; 106: 932-940. https://doi. org/10.1161/CIRCRESAHA.109.207415

[183] ZHOU HM, WESKAMP G, CHESNEAU V, SAHIN U, VORTKAMP A et al. Essential role for ADAM19 in cardiovascular morphogenesis. Mol Cell Biol 2004; 24: 96-104. https://doi.org/10.1128/MCB.24.1.96-104.2004

[184] KUROHARA K, KOMATSU K, KURISAKI T, MASUDA A, IRIE $N$ et al. Essential roles of Meltrin $\beta$ (ADAM19) in heart development. Dev Biol 2004; 267: 14-28. https://doi. org/10.1016/j.ydbio.2003.10.021

[185] HORIUCHI K, ZHOU HM, KELLY K, MANOVA K, BLOBEL CP. Evaluation of the contributions of ADAMs 9, $12,15,17$, and 19 to heart development and ectodomain shedding of neuregulins $\beta 1$ and $\beta 2$. Dev Biol 2005; 283: 459471. https://doi.org/10.1016/j.ydbio.2005.05.004

[186] WAKATSUKI S, YUMOTO N, KOMATSU K, ARAKI T, SEHARA-FUJISAWA A. Roles of meltrin- $\beta$ /ADAM19 in progression of schwann cell differentiation and myelination during sciatic nerve regeneration. J Biol Chem 2009; 284: 2957-2966. https://doi.org/10.1074/jbc.M803191200

[187] SAGANE K, HAYAKAWA K, KAI J, HIROHASHI T, TAKAHASHI E et al. Ataxia and peripheral nerve hypomyelination in ADAM22-deficient mice. BMC Neurosci 2005; 6: 33. https://doi.org/10.1186/1471-2202-6-33

[188] OZKAYNAK E, ABELLO G, JAEGLE M, VAN BERGE L, HAMER D et al. Adam22 Is a Major Neuronal Receptor for Lgi4-Mediated Schwann Cell Signaling. J Neurosci 2010; 30: 3857-3864. https://doi.org/10.1523/JNEUROSCI.6287-09.2010

[189] MITCHELL KJ, PINSON KI, KELLY OG, BRENNAN J, ZUPICICH J et al. Functional analysis of secreted and transmembrane proteins critical to mouse development. Nat Genet 2001; 28: 241-249. https://doi.org/10.1038/90074
[190] CHEN C, HUANG X, SHEPPARD D. ADAM33 Is Not Essential for Growth and Development and Does Not Modulate Allergic Asthma in Mice. Mol Cell Biol 2006; 26: 69506956. https://doi.org/10.1128/MCB.00646-06

[191] DAVIES ER, KELLY JFC, HOWARTH PH, WILSON DI, HOLGATE ST et al. Soluble ADAM33 initiates airway remodeling to promote susceptibility for allergic asthma in early life. JCI Insight 2016; 1: e87632. https://doi.org/10.1172/ jci.insight. 87632

[192] EBBING EA, MEDEMA JP, DAMHOFER H, MEIJER SL, KRISHNADATH KK et al. ADAM10-mediated release of heregulin confers resistance to trastuzumab by activating HER3. Oncotarget 2016; 7: 10243-10254. https://doi. org/10.18632/oncotarget.7200

[193] WOODS NK, PADMANABHAN J. Inhibition of amyloid precursor protein processing enhances gemcitabine-mediated cytotoxicity in pancreatic cancer cells. J Biol Chem 2013; 288: 30114-30124. https://doi.org/10.1074/jbc.M113.459255

[194] DONG F, EIBACH M, BARTSCH JW, DOLGA AM, SCHLOMANN $U$ et al. The metalloprotease-disintegrin ADAM8 contributes to temozolomide chemoresistance and enhanced invasiveness of human glioblastoma cells. Neuro Oncol 2015; 17: 1474-1485. https://doi.org/10.1093/neuonc/ nov042

[195] FU Q, CHENG J, ZHANG J, ZHANG Y, CHEN X et al. MiR$20 \mathrm{~b}$ reduces 5-FU resistance by suppressing the ADAM9/ EGFR signaling pathway in colon cancer. Oncol Rep 2017; 37: 123-130. https://doi.org/10.3892/or.2016.5259

[196] WANG R, YE X, BHATTACHARYA R, BOULBES DR, FAN F et al. A Disintegrin and Metalloproteinase Domain 17 Regulates Colorectal Cancer Stem Cells and Chemosensitivity Via Notch1 Signaling. Stem Cells Transl Med 2016; 5: 331-338. https://doi.org/10.5966/sctm.2015-0168

[197] YANG CL, JIANG FQ, XU F, JIANG GX. ADAM10 overexpression confers resistance to doxorubicin-induced apoptosis in hepatocellular carcinoma. Tumor Biol 2012; 33: 15351541. https://doi.org/10.1007/s13277-012-0405-4

[198] PARK G, CHUNG Y, KIM D. 2-Deoxy-D-glucose suppresses the migration and reverses the drug resistance of colon cancer cells through ADAM expression regulation. Anticancer Drugs 2017: 28: 410-420. https://doi.org/10.1097/ CAD.0000000000000472

[199] VAN SCHAEYBROECK S, KALIMUTHO M, DUNNE PD, CARSON R, ALLEN W et al. ADAM17-dependent c-METSTAT3 signaling mediates resistance to MEK inhibitors in KRAS mutant colorectal cancer. Cell Rep 2014; 7: 19401955. https://doi.org/10.1016/j.celrep.2014.05.032

[200] WANG XJ, FENG CW, LI M. ADAM17 mediates hypoxiainduced drug resistance in hepatocellular carcinoma cells through activation of EGFR/PI3K/Akt pathway. Mol Cell Biochem 2013; 380: 57-66. https://doi.org/10.1007/s11010$013-1657-z$

[201] VINCENT B. Regulation of the $\alpha$-secretase ADAM10 at transcriptional, translational and post-translational levels. Brain Res Bull 2016; 126: 154-169. https://doi.org/10.1016/j. brainresbull.2016.03.020 